\title{
Air quality improvement and its relation to mobility during COVID-19 lockdown in Marmara Region, Turkey
}

\author{
Bahtiyar Efe ${ }^{\mathbb{D}}$
}

Received: 26 June 2021 / Accepted: 17 February 2022 / Published online: 7 March 2022

(C) The Author(s), under exclusive licence to Springer Nature Switzerland AG 2022

\begin{abstract}
The outbreak of the novel coronavirus SARS-CoV-2 (hereafter COVID-19) has changed the daily routines of people around the world. When the first case was confirmed on 11 March 2020 in Turkey, the number of cases reached 4500 per day by 10 April in Turkey. Afterwards, the government declared more restrictive lockdown measures for 31 metropolitan cities starting 10 April, and it was implemented for the following weekends, national, and religious holidays. The change in concentrations of $\mathrm{PM}_{10}, \mathrm{PM}_{2.5}$, and $\mathrm{NO}_{2}$ during these measures with respect to the pre-lockdown period, the same period in the previous years and for different levels of measures for the cities in the Marmara Region of Turkey was investigated in this study. The daily mean concentrations of $\mathrm{PM}_{10}$, $\mathrm{PM}_{2.5}$, and $\mathrm{NO}_{2}$ obtained from 11 stations operated by the Ministry of Environment and Urbanization and Google mobility data are used in this study. Average $\mathrm{PM}_{2.5}$ and $\mathrm{NO}_{2}$ concentrations during the lockdown period declined with respect to the pre-lockdown period and the previous year for all stations. Average $\mathrm{PM}_{10}$ concentrations during the lockdown of 8 of 11 stations declined, while the rest of the stations increased with respect to the pre-lockdown period. In 9 of the 11 stations, the average concentration of $\mathrm{PM}_{10}$ decreased compared to the previous four years.
\end{abstract}

B. Efe $(\bowtie)$

Department of Meteorological Engineering, University of Samsun, 19 Mayis, Samsun, Turkey

e-mail: bahtiyar.efe@samsun.edu.tr
In 7 of the 11 stations, the number of days exceeding WHO limit for $\mathrm{PM}_{10}$ was decreased during the lockdown period with respect to the pre-lockdown period. For $\mathrm{PM}_{2.5}$, the number of days exceeding WHO limit was decreased during the lockdown period compared to the pre-lockdown period for all the stations. For $\mathrm{NO}_{2}$, the number of days exceeding WHO limit was decreased during the lockdown period compared to the pre-lockdown period for 7 of the 8 stations. There is a significant relationship between mobility decrease and $\mathrm{NO}_{2}$ concentrations in large cities. The correlation coefficients are generally lower in small cities in the study region.

Keywords COVID-19 - Air pollution · Turkey · Marmara Region

\section{Introduction}

On the 11th of March 2020, the World Health Organization declared the SARS-CoV-2 (hereinafter COVID-19) as a pandemic, and on the same day the first positive case was detected in Turkey. The first partial lockdowns on weekend days in late March and April in some major cities were declared by the government. In addition, 3 and 4-day lockdowns including national holidays with social distancing have been implemented to prevent spreading the coronavirus. Across the country, intercity travel has been restricted from 27 March. However, despite these measures, the 
number of cases reached 4500 per day until the 10th of April. As of August 30, 2020, a cumulative total of 25 million confirmed cases and around 800,000 deaths have been reported globally since the start of the outbreak (WHO, 2020). All these restrictions have shut down industries and business sectors, drastically reduced motor vehicle traffic, and had a huge impact on people's social activities. Hence, the measures led to a decrease in air pollution emissions.

Numerous studies have reported on improvements in air quality due to the effects of COVID-19 based on partial and total lockdown measures (e.g., Baldasano, 2020; Collivignarelli et al., 2020; Nakada \& Urban, 2020; Tobias et al., 2020; Siciliano et al., 2020; Sicard et al., 2020; Şahin, 2020; Dantas et al., 2020; Li \& Tartarini, 2020; Xu et al., 2020; Wetchayont, 2021; Hashim et al., 2021). Xu et al. (2020) indicated that the effects of the COVID-19 outbreak presented significant reductions in the concentrations of $\mathrm{PM}_{2.5}, \mathrm{PM}_{10}, \mathrm{SO}_{2}$, $\mathrm{CO}$, and $\mathrm{NO}_{2}$ in China. Similar behaviors and reductions were also found in some Southeast Asian cities such as Bangkok, Kuala Lumpur, Singapore, and Manila. For example, Wetchayont (2021) presented a significant decreasing trend during the COVID-19outbreak year based on the periods before lockdown, lockdown and after lockdown periods for the concentrations of $\mathrm{PM}_{2.5}, \mathrm{PM}_{10}, \mathrm{O}_{3}$, and $\mathrm{CO}$ in Bangkok. Besides, Siciliano et al. (2020) discussed the impact of the partial lockdown on the ozone levels in the city of Rio de Janeiro, Brazil. A similar study has been conducted by Baldasano (2020) for Barcelona and Madrid during lockdown measures. He studied $\mathrm{NO}_{2}$ values of Barcelona and Madrid during lockdown measures and found that the $\mathrm{NO}_{2}$ concentration was significantly reduced by $50 \%$ and $62 \%$, respectively. Additionally, Tobias et al. (2020) showed that quarantine measures led to an improvement in air quality in Barcelona.

Significant results were also found in several European cities such as Barcelona, Istanbul, Madrid, Milan, and Munich. In addition, Şahin (2020) found significant decreases during March 2020 in Istanbul. For example, she reported reductions in $\mathrm{PM}_{10}$ (32-43\%), $\mathrm{PM}_{2.5}$ (19-47\%), $\mathrm{NO}_{2}$ (29-44\%), $\mathrm{CO}(40-58 \%)$, and $\mathrm{SO}_{2}$ (34-69\%), respectively.

Meanwhile, several studies have used the mobility data to better understand the relationship between air pollution measurements and mobility during the COVID 19 measures (Li \& Tartarini, 2020; Wang et al., 2020; Zhu et al., 2020). Li and Tartarini (2020) declared that trends of $\mathrm{PM}_{2.5}$ and $\mathrm{NO}_{2}$ were significantly correlated with mobility data for Singapore. Wang et al. (2020) investigated the effect of population mobility and airborne particulate matter on the spread of COVID-19 in several cities in China and concluded that the risk of COVID-19 transmission may be associated with mobility and airborne particulate matter. In addition, Zhu et al. (2020) studied the mediating effect of air pollution on the association of human mobility and spread of COVID-19. They concluded the unit increase in human mobility index is associated with an increase of $6.45 \%$ of the daily confirmed cases with the mediating effect of air quality index of $19.47 \%$.

Marmara region which is located in the northwest of Turkey (Fig. 1) is the major economic region in Turkey in terms of industry, trade, tourism, and agriculture. About 25 million people live in eleven cities in this region. Table 1 presents the air quality stations and their characteristics.

Air pollution for the Marmara Region and in particular for Istanbul was investigated from different perspectives. Unal et al. (2011) investigated the influence of meteorological factors on spatial and temporal variations of $\mathrm{PM}_{10}$ concentrations in Istanbul. Kasparoglu et al. (2018) investigated the spatial and temporal variations of $\mathrm{O}_{3}$ and $\mathrm{NO}_{x}$ concentrations at 7 rural and 15 urban sites in the Marmara Region of Turkey. They showed that the results indicate that surface $\mathrm{O}_{3}$ is an extensive problem throughout the Marmara Region. Im et al. (2010) studied the $\mathrm{PM}_{10}$ episode in Istanbul using couple weather research and forecast model and air quality model. They conclude that, the new inventory used for Istanbul improved the $\mathrm{PM}_{10}$ assessment results compared to the previous model studies. Çapraz et al. (2016) investigated the association between air pollution and mortality in Istanbul for the period of 2007-2012. They found that mortality from cardiovascular disease, respiratory diseases, and total non-accidental causes in İstanbul are related to air pollution.

The COVID-19 lockdown's impact on air quality in the Marmara region is currently unknown except partly in Istanbul. Therefore, this study aims to assess the variations of air quality concentrations from the 11 stations and evaluate their associations with mobility trends during the COVID-19 partly lockdown measures by using statistical analysis.

The outbreak of the novel coronavirus COVID-19 has changed the daily routines for the lives of people 


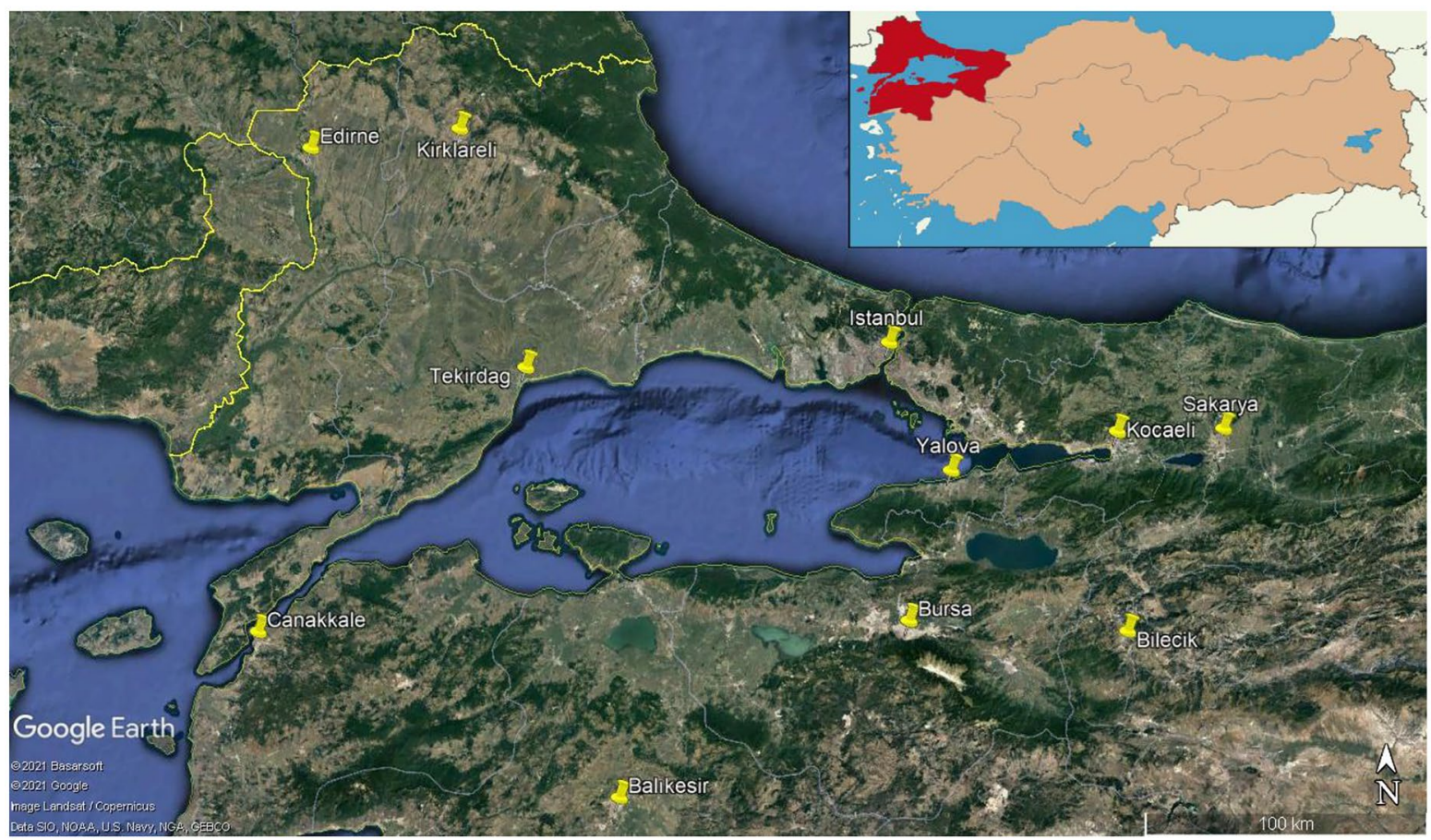

Fig. 1 The Marmara Region and location of air quality monitoring stations (Google Earth, 2021 \& Wikipedia, 2021)

all over the world. The first case of the virus appeared in Wuhan, China, which is well known as one of the world's biggest trade and transportation centers, in December 2019. The virus has spread worldwide in a short period of time and the World Health Organization (WHO) has declared it as a global pandemic by 11 March 2020 (WHO, 2020). Most of the world's national governments took action by introducing strict rules to control the spread of the virus after they confirmed the first cases in their countries.

As a precaution, international flights to China, Iran, and Italy which were already experiencing strong

Table 1 Description of the urban air quality stations in the Marmara Region used in this study

\begin{tabular}{|c|c|c|c|c|c|c|}
\hline Station & $\mathrm{PM}_{10}$ & $\mathrm{PM}_{2.5}$ & $\mathrm{NO}_{2}$ & $\begin{array}{l}\text { Distance to residential } \\
\text { areas }(\mathrm{m})\end{array}$ & $\begin{array}{l}\text { Distance to industrial } \\
\text { areas }(\mathrm{km})\end{array}$ & $\begin{array}{l}\text { Distance to } \\
\text { major roads } \\
(\mathrm{km})\end{array}$ \\
\hline Balıkesir & 2016-2020 & 2019-2020 & 2019-2020 & 126 & 2.7 & 0.82 \\
\hline Bilecik & 2016-2020 & 2019-2020 & - & 25 & 3.3 & 0.17 \\
\hline Bursa & 2016-2020 & - & 2019-2020 & 425 & 0.5 & 0.64 \\
\hline Çanakkale & $2016-2020$ & 2019-2020 & 2019-2020 & 25 & 7.1 & 1.09 \\
\hline Edirne & 2016-2020 & 2019-2020 & 2019-2020 & 35 & 5.2 & 0.16 \\
\hline İstanbul & 2016-2020 & 2019-2020 & 2019-2020 & 120 & 5.7 & 0.01 \\
\hline Kirklareli & 2016-2020 & 2019-2020 & 2019-2020 & 76 & 1.3 & 0.1 \\
\hline Kocaeli & 2016-2020 & 2019-2020 & 2019-2020 & 252 & 3.6 & 0.32 \\
\hline Sakarya & $2016-2020$ & 2019-2020 & - & 30 & 0.8 & 2.34 \\
\hline Tekirdağ & 2016-2020 & 2019-2020 & - & 25 & 0.8 & 1.15 \\
\hline Yalova & 2016-2020 & 2019-2020 & 2019-2020 & 140 & 12.7 & 2.01 \\
\hline
\end{tabular}


increases in confirmed cases, were canceled before the first case was diagnosed in Turkey. After the first case was confirmed in Turkey on 11 March 2020, the authorities first closed the airway transportation, then the borders to most of EU and neighbor countries. The primary, secondary and post-secondary schools stopped teaching in-class by 17 March, and they switched to online teaching. Indoor and outdoor gatherings were postponed or canceled as well as restaurants, cafes, and gyms closing by 20 March. Later, there were several actions undertaken such as closing non-essential businesses, stay-at-home orders, applying social distance measures and lockdown measures. Nationwide, intercity travels were limited by 27 March. However, in spite of these measures, the number of cases reached 4500 per day by 10 April. Afterwards, the government declared more restrictive lockdown measures for 31 metropolitan cities starting 10 April, and it was implemented for the following weekends, national and religious holidays. These full lockdown measures were removed by 1 June (Wikipedia, 2020). All these restrictions changed people's daily life routines and directly affected the daily commute. Therefore, it could be expected that the level of air pollution in these cities were lower with the COVID-19 lockdown measures.

The impact of COVID-19 on local air pollution has already been investigated. Several research groups have published recently about the change in ambient pollutant concentrations in major cities around the world (Adams, 2020; Baldasano, 2020; Lian et al., 2020; Menut et al., 2020; Otmani et al., 2020; Zangari et al., 2020). Adams (2020) investigated the air pollution in Ontario, Canada during COVID-19 and stated that $\mathrm{NO}_{2}, \mathrm{NO}_{\mathrm{x}}$, and $\mathrm{O}_{3}$ decreased during study period, while $\mathrm{PM}_{2.5}$ did not change.

A study was published recently for Istanbul as well (Şahin, 2020). Although studies conducted on changes in local concentrations have shown a link between air pollution and impact of the restrictions imposed by COVID-19, early studies also indicate that ambient concentrations may be affected in a regional and global scale. For example, the study conducted by Menut et al. (2020) for Western Europe concludes that lockdown measures caused a decline in $\mathrm{PM}$ and $\mathrm{NO}_{2}$ concentrations due to low traffic volume. Another research article (Rodriguez-Urrego and RodriguezUrrego, 2020) showed that $\mathrm{PM}_{2.5}$ concentrations in 50 densely populated cities around the world have been reduced by $12 \%$. Besides, a more comprehensive study (Venter et al., 2020) also found evidence of COVID-19's impact on tropospheric and ground level concentrations. They demonstrated the reduction of $\mathrm{NO}_{2}$ and $\mathrm{PM}_{2.5}$ while a marginal increase in $\mathrm{O}_{3}$ concentrations was noted, and they also identified a relationship between these changes in concentrations and traffic volume. Additionally, Chu et al. (2020) investigates the behaviour of $\mathrm{PM}_{2.5}$ and $\mathrm{NO}_{2}$ pollution in China, and they found a reduction in $\mathrm{PM}_{2.5}$ levels of $35 \%$ for China (Hubei excluded) with less significant decreases in $\mathrm{SO}_{2}$ and $\mathrm{CO}$. As expected, they also report that there was an increase in $\mathrm{O}_{3}$ concentration. Lastly, a study was conducted by Shehzad et al. (2020) using satellite and monitoring data for India, and this study showed a significant decrease in NO2 concentrations. Almost all studies suggest a very important degree for the decline in pollutant concentrations for different locations around the world.

In this study, the link between the COVID-19 lockdown measures and their impact on the ambient air quality concentrations in the Marmara region of Turkey was examined. There are 11 cities in the region, 6 of which have a population of more than 1 million. Also, this region is well-known for its industrial zones. In addition, some previous studies have examined air pollution in the region (Kahya et al., 2017; Kasparoglu et al., 2018) previously. However, we use traffic-related monitoring sites and focus more on the change in traffic-related background concentrations.

This study is based on regional basis analysis and contributed to the latest literature on air pollution during the COVID-19 pandemic. Additionally, we compare concentrations during the periods in which lockdown measures were implemented and compare these to the same periods during non-pandemic years. This study also includes Google's mobility data which helps to explain the results quantitatively. The presented study is different than that by Şahin (2020). This study considers the pre-lock down period from the 1st of January to the 17th of March, while it was a limited period in the period of 1-15 March. The study area covers the Marmara Region while in that study, only Istanbul was taken into consideration. Şahin (2020) compares the mean values of pollutant concentrations in only two periods, before lockdown and after lockdown. In this study, the average concentrations during the lockdown were evaluated relative to other periods as well as pre-lockdown. Furthermore, this study considers the 
mobility data in order to find a link between the mobility values and the average concentrations.

This paper is organized as follows: the study area, air pollution data and methodology are described in "Data and methodology". The results are presented in "Results and discussion," and the main conclusions are drawn in "Conclusion".

\section{Data and methodology}

Study area

The Marmara Region is located in the northwestern part of Turkey and contains the 11 cities studied here. The Sea of Marmara is the inland waters of the region, and seven of these cities are located on the shore of the Sea of Marmara. In addition, five cities (Istanbul, Tekirdağ, Kırklareli, Kocaeli, and Sakarya) are situated on the coast of the Black Sea, and three (Çanakkale, Balıkesir, Edirne) have a coastal zone on the Aegean Sea (Fig. 1). The region has an area of about $68,000 \mathrm{~km}^{2}$ with a complex terrain, and this area corresponds to $8.5 \%$ of Turkey's total area.

Marmara Region is selected as the study area because of its large number of population, important amount of industrial production, and its busy railways. According to the address-based population registration system, the Marmara region has a total population of $25,731,357$. That means $30 \%$ of Turkey's population lives in this region. Istanbul, one of the megacities in the world with a population of more than 15 million is also located in this region (TUIK, 2021a). The Marmara region is responsible for $48 \%$ of the industrial production developed in Turkey, and there is a diverse array of industries operating in the region (Demirarslan \& Akınc1, 2018). There are 7,445,695 motor vehicles in the region, accounting for $31 \%$ of total number of motor vehicles in Turkey. The number of cars is 4,561,594, and it is one-third of the total cars in Turkey. Gasoline-powered cars are $24.4 \%$ of the total cars and those of diesel are $38.3 \%$, which means there are about 1.1 million gasoline-powered cars and 1.75 million diesel-powered cars. (TUIK, 2021b).

Air quality data

Major air pollutants including $\mathrm{PM}_{10}, \mathrm{PM}_{2.5}$, and $\mathrm{NO}_{2}$ measured by the Marmara Clean Air Center (MCAC)
(10 stations) and Greater Istanbul Municipality (1 station) used in the study were shown in Table 1. All the stations are urban air quality stations, and their distance to industrial areas changes between 0.8 and $12.7 \mathrm{~km}$. The distance of the stations to the major roads vary between 10 and $2.34 \mathrm{~km}$. The $\mathrm{PM}_{10}$ data are available for the period 2016-2020 at all stations. The $\mathrm{PM}_{2.5}$ data are available for the 2019-2020 period at 10 stations, while $\mathrm{NO}_{2}$ is available for only eight stations during the same period. Beta-ray absorption method is used in PM analyzer and measures between 0 and $10.000 \mu \mathrm{g} / \mathrm{m}^{3}$. PM measurement devices (Environnement SA MP101M, Thermo 5014i, Metone Bam 1020, Environnement SA PM162M, MCZ LVS16, LECKEL SEQ 47/50, and MCV HVS1) are being operated compatibly with EN 12,341 for $\mathrm{PM}_{10}$ and EN 14,907 for $\mathrm{PM}_{2.5}$. The measurements of $\mathrm{NO}_{2}$ are made using a Teledyne API-M200E nitrogen oxide analyzer by using chemiluminescence method and has a measurement range of 0-200 ppm. Certificated calibration gasses were used to calibrate gas analysis devices regularly. Data validation is conducted routinely by the Marmara Clean Air Center and Greater Istanbul Municipality. Additionally, all the data were checked to get irregular measurements, like zero and negative values. This data is widely used by researchers (Kasparoglu et al., 2018; Şahin, 2020, Çapraz et al., 2016). $\mathrm{PM}_{10}$ emissions on traffic originate from diesel vehicles rather than the gasoline-powered ones. Besides, most of the trucks, such as buses and commercial vehicles in transport and construction sectors, are powered by the diesel system (Unal et al., 2011). The $\mathrm{PM}_{2.5}$ data are available for the 2019-2020 period at 10 stations, while $\mathrm{NO}_{2}$ is available for only eight stations during the same period. Main sources of $\mathrm{PM}_{2.5}$ are car and truck exhausts, industry, smoke from fires and residential heating. $\mathrm{NO}_{2}$ is mostly emitted by combustion sources, e.g., car engines, residential heating, power plants, industries, and biomass burning. The number of the days exceeding the limit values of each pollutant according to World Health Organization (WHO, 2018) is also calculated. The annual average of the pollutants for each station is also calculated, and the level of 2020 is compared to the previous available years. According to $\mathrm{WHO}$ guideline limits of $\mathrm{PM}_{10}, \mathrm{PM}_{2.5}$, and $\mathrm{NO}_{2}$ for $24 \mathrm{~h}$ are $45 \mu \mathrm{g} /$ $\mathrm{m}^{3}, 15 \mu \mathrm{g} / \mathrm{m}^{3}$, and $25 \mu \mathrm{g} / \mathrm{m}^{3}$, respectively. The annual limits for $\mathrm{PM}_{10}, \mathrm{PM}_{2.5}$, and $\mathrm{NO}_{2}$ are $15 \mu \mathrm{g} / \mathrm{m}^{3}, 5 \mu \mathrm{g} /$ $\mathrm{m}^{3}$, and $10 \mu \mathrm{g} / \mathrm{m}^{3}$, respectively. 
Some periods were chosen to make the comparisons of the pollutant concentrations. The first period is defined as the pre-lockdown period (hereafter PLD) covering the period from 1 January-17 March 2020. The second period is called the lockdown measures period (hereafter LDM) covering the dates from 18 March-1 June 2020. The third period is the post (or after) lockdown period (hereafter ALD) covering the period from 1 June to 31 August 2020. The change for the concentrations of $\mathrm{PM}_{10}, \mathrm{PM}_{2.5}$, and $\mathrm{NO}_{2}$ were analyzed for three different steps. For the first step, the change of concentrations during LDM and ALD with respect to the PLD is investigated. This step may not provide valuable results due to seasonal effects because average concentrations of all the pollutants in this study decrease from winter to summer. In addition, the number of the days exceeding the WHO limits during the LDM period is compared to the number of days exceeding the WHO limits during the PLD period.

For the second step, the LDM period was divided into two parts; the first one covers the dates that full lockdown measures were applied for metropolitan cities (hereafter FLD), and the second covers the remaining FLD days (hereafter RFLD). The change in concentrations of air pollutants during FLD with respect to the RFLD days is then investigated.

In the third step, the change of the mean $\mathrm{PM}_{10}$ concentration during the LDM with respect to the mean $\mathrm{PM}_{10}$ concentrations for the same period during the previous 4 years. This step also investigates the change for the mean $\mathrm{PM}_{2.5}$ and $\mathrm{NO}_{2}$ concentrations during the LDM with respect to the same quantities of the same period of the previous year (2019). The $\mathrm{PM}_{2.5}$ and $\mathrm{NO}_{2}$ observations are compared to the previous year only due to data availability.

In the fourth step, the mean $\mathrm{PM}_{10}$ concentration is compared to the mean $\mathrm{PM}_{10}$ concentrations of the previous 4 years. This step also investigates the change for the mean $\mathrm{PM}_{2.5}$ and $\mathrm{NO}_{2}$ concentrations during 2020 with respect to the mean $\mathrm{PM}_{2.5}$ and $\mathrm{NO}_{2}$ concentrations of 2019. The $\mathrm{PM}_{2.5}$ and $\mathrm{NO}_{2}$ observations are compared to the previous year only due to data availability.

\section{Mobility data}

In this part of the study, datasets from Google were used to analyze how changes in mobility affected the air quality. In addition to the Google dataset, Apple dataset for driving was used in the Marmara region, which is only available for Istanbul and Bursa cities.

The mobility data provided by Google (2020) for public health officials are used in this study to understand the observed reduction in traffic. The mobility data is explained in six different categories as introduced by Google (2020). These categories are retail and recreation percent change, grocery and pharmacy percent change, park percent change, transit station percent change, workplace percent change, and residential percent change. Workplace mobility data are used to represent the traffic change, since people use many kinds of vehicles to go to work. The mobility data are represented as the percent change from a base line in the six categories. The baseline is the median value of mobility data covering the 5-week period from 3 January-6 February 2020.

Apple provides mobility data which is classified into only two categories: driving and walking. The data depends on the navigation query change done by Apple users in a day with respect to the navigation queries done in January 13, 2020. Navigation queries for driving provided by Apple are used in this study as mobility data. Apple data is available for only Istanbul and Bursa cities. Real traffic data of a location (41.06415 N, 28.99841 E) located close to the Istanbul air quality station is obtained from Greater Istanbul Municipality (2020) to get more insight about traffic reduction.

In this study, mobility data is used to show a relative trend of how people movements changed within the region each day as in $\mathrm{Li}$ and Tartarini (2020). Mobility data is highly correlated not only with air quality but also with the spread of COVID-19. Yilmazkuday (2021) concluded that, his study shows less mobility is associated with a decrease in COVID19 cases and deaths. He used Google mobility data of 130 countries for the period of February 15 and May 2, 2020. Therefore, mobility has been included to our study. The relationship between mobility change and decline in air pollution levels are analyzed by Pearson's correlation coefficient. More details on Pearson's correlation coefficient should be found in Benesty et al. (2009) and references therein. All the figures were illustrated via the ggplot2 R-package (Wickham, 2016). All the calculations are done using R-programming (R Core Team, 2018; Wickham et al., 2018). 


\section{Results and discussion}

$\mathrm{PM}_{10}$ concentration

Daily $\mathrm{PM}_{10}$ concentrations from the PLD during LDM and ALD are shown as time series located on the outer part of Fig. 2. The blue arrows indicate the decline of LDM and ALD with respect to PLD, while red arrows indicate increment. As seen in Fig. 2, most of the cities experience a decline of $\mathrm{PM}_{10}$ concentrations during both the LDM and ALD periods, while Yalova and Çanakkale demonstrate an increase during both periods. Besides, the Tekirdağ station shows an increase during the LDM period and a decrease during the ALD period, while the Edirne station shows the opposite changes. The colored big map of the region in the center of Fig. 2 describes the change in mean $\mathrm{PM}_{10}$ concentration during the LDM with respect to the mean $\mathrm{PM}_{10}$ concentrations during the same period from the previous 4 years.
The rate of decrease for the mean $\mathrm{PM}_{10}$ concentrations at all stations during the LDM with respect to PLD fluctuates between 14 (Kocaeli) and 30 (Bursa) percent except for the Çanakkale, Tekirdağ, and Yalova stations (Table 2; Fig. 2). The average for the region is decreased by $13 \%$. The $\mathrm{PM}_{10}$ concentrations increased at Çanakkale, Tekirdağ, and Yalova by 3,22 , and $6 \%$, respectively. The cause of this increase is two $\mathrm{PM}_{10}$ episodes created by the dust transport from western Turkey. All the stations that were in the inner band of the Marmara Region experienced the first episode, but the concentration levels are different. The second one is experienced by all the stations used in this study. Thus, all the stations experienced $\mathrm{PM}_{10}$ episodes at different levels, but the mean $\mathrm{PM}_{10}$ concentrations for each of the stations with lower background pollution levels increased. Western Turkey experiences Sharan dust transport during the whole year as supported by observations (Baltaci, 2017; Kabatas et al., 2018) and model

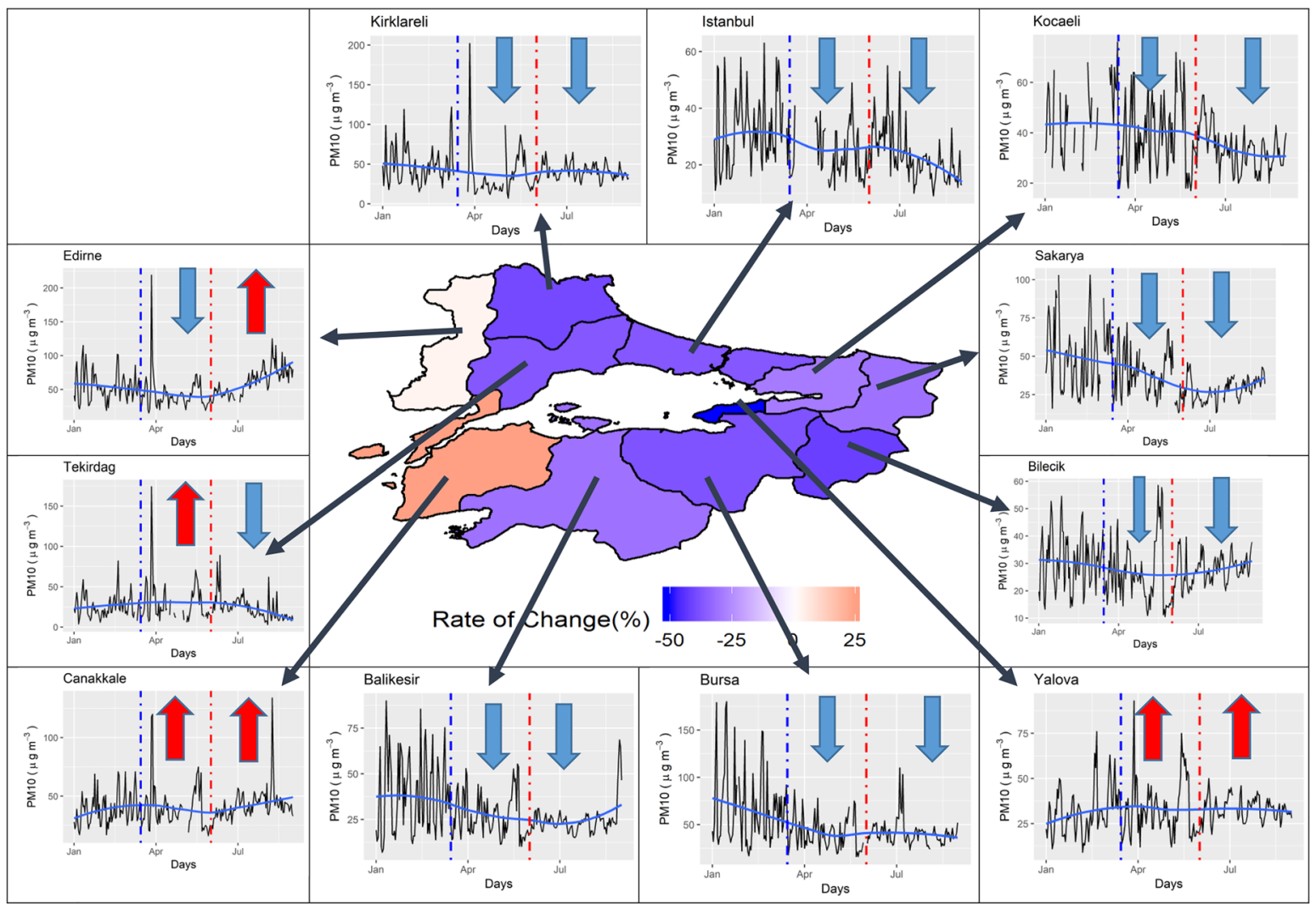

Fig. 2 (a) Outer time series represent the daily mean $\mathrm{PM}_{10}$ concentrations for the period of January 1-August 31, 2020. (b) Inner map represents the change of mean the $\mathrm{PM}_{10}$ concen- tration during LDM with respect to the mean $\mathrm{PM}_{10}$ concentrations of the same period of the previous 4 years 
Table 2 Average $\mathrm{PM}_{10}$ concentrations during PLD, LDM, ALD periods, and the change of $\mathrm{PM}_{10}$ concentrations during LDM and ALD with respect to PLD

\begin{tabular}{llllll}
\hline & $\begin{array}{l}\text { Average }(\text { PLD) } \\
\left(\mu \mathrm{g} / \mathrm{m}^{3}\right)\end{array}$ & $\begin{array}{l}\text { Average }(\mathrm{LDM}) \\
\left(\mu \mathrm{g} / \mathrm{m}^{3}\right)\end{array}$ & $\begin{array}{l}\text { Rate of } \\
\text { change }(\%)\end{array}$ & $\begin{array}{l}\text { Average (ALD) } \\
\left(\mu \mathrm{g} / \mathrm{m}^{3}\right)\end{array}$ & $\begin{array}{l}\text { Rate of } \\
\text { change } \\
(\%)\end{array}$ \\
\hline Balıkesir & 37.7 & 26.7 & -29 & 24.2 & -35 \\
Bilecik & 30.3 & 25.7 & -15 & 27.2 & -10 \\
Bursa & 66.7 & 40.6 & -30 & 40.9 & -30 \\
Çanakkale & 38.6 & 40.1 & +3 & 42.6 & +10 \\
Edirne & 54.1 & 43.1 & -20 & 62.2 & +15 \\
İstanbul & 31.8 & 23.9 & -25 & 23.0 & -27 \\
Kirklareli & 48.1 & 36.4 & -24 & 40.5 & -15 \\
Kocaeli & 45.8 & 39.3 & -14 & 33.4 & -27 \\
Sakarya & 49.9 & 37.5 & -24 & 28.6 & -42 \\
Tekirdag & 25.4 & 31.3 & +22 & 23.3 & -8 \\
Yalova & 31.3 & 32.9 & +6 & 33.0 & +6 \\
\hline
\end{tabular}

(Agacayak et al., 2015; Kabatas et al., 2018) studies. Otmani et al. (2020) found a decrease in $\mathrm{PM}_{10}$ measurements of $75 \%$ for Sale City located in NW Morocco, and Lian et al. (2020) found an average decline about $15 \%$ for the cities in Hubei Province. The previous one considers only one station, while the latter considers 12 stations. Our results are consistent with these studies.

The rate of change kept decreasing during the ALD as seen in Fig. 2 and Table 2 in the range of 8 (Tekirdağ) and 42 (Sakarya) percent except for Çanakkale, Edirne, and Yalova. The average for the region is decreased by $15 \%$. These three stations experienced increases in PM10 concentrations by 10, 15, and 6\%, respectively. The only cause of the increase at Çanakkale is the $\mathrm{PM}_{10}$ episode. In Edirne, the mean $\mathrm{PM}_{10}$ levels increased by the $\mathrm{PM}_{10}$ episode and also by the background levels of $\mathrm{PM}_{10}$. The increase in Yalova is created by only an increase in background levels. The main source of $\mathrm{PM}_{10}$ is domestic heating in large cities. However, in small cities the main contributor may be different. So, the behavior of $\mathrm{PM}_{10}$ in small cities such as Çanakkale, Edirne, and Yalova may vary due to emission sources.

The exceedance numbers of $\mathrm{PM}_{10}$ limits during PLD and LDM are seen in Table 3. The number of exceedances in the region varies between 6 and 45 in the region with the mean of 24 days during PLD.
During LDM the exceedance numbers varies between 1 and 26 days with the average of 15 days. The average exceedance number of the region during LDM declined 47\% with respect to PLD. Maximum decline in exceedance number was observed in Istanbul with the value of $92 \%$. There is also an increment in exceedance numbers in some stations. Tekirdağ observed the maximum increment during LDM with respect to PLD with the value of $133 \%$. Overall, metropolitan cities experienced decline of exceedance numbers, while small cities experienced both decline and increment.

The mean concentrations of $\mathrm{PM}_{10}$ during subLDM periods are seen in Table 4. All the stations experience a decline of $\mathrm{PM}_{10}$ during FLD with respect to RFLD days, with the region average of $25 \%$. The decline rates vary between 17 and 39\%. Kocaeli and Yalova are the stations with smaller declines of 17 and $20 \%$. Yalova is not a metropolitan city, so the decline is smaller here because a full lockdown on weekends is not applied in small cities. The Kocaeli station is located near the industrial areas so the decline is the lowest since the factories did not close during lockdown measures. There are two cement and metal factories within a 5-km distance of Kocaeli station. The higher decline in values is observed at the Tekirdağ and Sakarya stations with 39 and 28\%. Even though Tekirdağ and Sakarya are metropolitan cities in which lockdown measures were undertaken, the
Table 3 The exceedance number of $\mathrm{PM}_{10}$ limits during PLD and LDM

\begin{tabular}{llllllllllll}
\hline & Balı & Bilec & Bursa & Cana & Edir & İsta & Kırk & Koca & Saka & Teki & Yalo \\
\hline PLD & 29 & 6 & 45 & 19 & 49 & 12 & 32 & 21 & 40 & 6 & 10 \\
LDM & 6 & 6 & 26 & 18 & 22 & 1 & 15 & 25 & 20 & 14 & 15 \\
\hline
\end{tabular}


Table 4 The average $\mathrm{PM}_{10}$ concentrations during subLDM periods, FLD and RFLD, and change of mean $\mathrm{PM}_{10}$ concentrations during FLD with respect to RFLD

\begin{tabular}{llll}
\hline & $\begin{array}{l}\text { Average (FLD) } \\
\left(\mu \mathrm{g} / \mathrm{m}^{3}\right)\end{array}$ & $\begin{array}{l}\text { Average (RFLD) } \\
\left(\mu \mathrm{g} / \mathrm{m}^{3}\right)\end{array}$ & $\begin{array}{l}\text { Rate of } \\
\text { change } \\
(\%)\end{array}$ \\
\hline Balıkesir & 21.1 & 28.1 & -25 \\
Bilecik & 20.8 & 27.0 & -23 \\
Bursa & 31.7 & 43 & -26 \\
Çanakkale & 31.6 & 41.8 & -24 \\
Edirne & 34.5 & 45.3 & -24 \\
İstanbul & 19.6 & 25.6 & -23 \\
Kirklareli & 29.8 & 38.2 & -22 \\
Kocaeli & 33.7 & 40.7 & -17 \\
Sakarya & 28.7 & 39.8 & -28 \\
Tekirdag & 19.9 & 32.8 & -39 \\
Yalova & 27.4 & 34.2 & -20 \\
\hline
\end{tabular}

population of these two cities is relatively lower compared to the other metropolitan cities in the region. centration during the LDM with respect to the mean $\mathrm{PM}_{10}$ concentrations during the same period for the previous 4 years are investigated. All the stations except Edirne and Çanakkale experienced a decline
Lastly, the change rate for the average $\mathrm{PM}_{10}$ con-

Table 5 The average $\mathrm{PM}_{10}$ concentrations during LDM and the same period of the previous 4 years, and the change of concentrations during LDM with respect to the previous 4 years

\begin{tabular}{llll}
\hline & $\begin{array}{l}\text { Average } \\
\text { LDM } \\
(2020)\end{array}$ & $\begin{array}{l}\text { Average of March 17-June } \\
\text { 1 of previous 4 years } \\
(2016-2019)\end{array}$ & $\begin{array}{l}\text { Rate of } \\
\text { change } \\
(\%)\end{array}$ \\
\hline Balıkesir & 26.7 & 38.8 & -31 \\
Bilecik & 25.7 & 44.5 & -42 \\
Bursa & 40.6 & 76.2 & -38 \\
Çanakkale & 40.1 & 32 & +25 \\
Edirne & 43.1 & 41.8 & +3 \\
İstanbul & 23.9 & 44.2 & -46 \\
Kırklareli & 36.4 & 61.5 & -40 \\
Kocaeli & 39.3 & 55.6 & -29 \\
Sakarya & 37.5 & 54.4 & -31 \\
Tekirdag & 31.1 & 49.7 & -37 \\
Yalova & 32.9 & 66.4 & -51 \\
\hline
\end{tabular}

during the LDM (Table 5) with the region average of decline $29 \%$. The decline rates fluctuate between 29 and 51\%. Kocaeli and Sakarya are the stations with the smallest decreases, 29 and 31\%, respectively, while İstanbul and Yalova experienced the largest declines, 46 and 51\%, respectively. Çanakkale and Edirne exhibited different behaviors than

Fig. 3 The annual mean concentrations of $\mathrm{PM}_{10}$
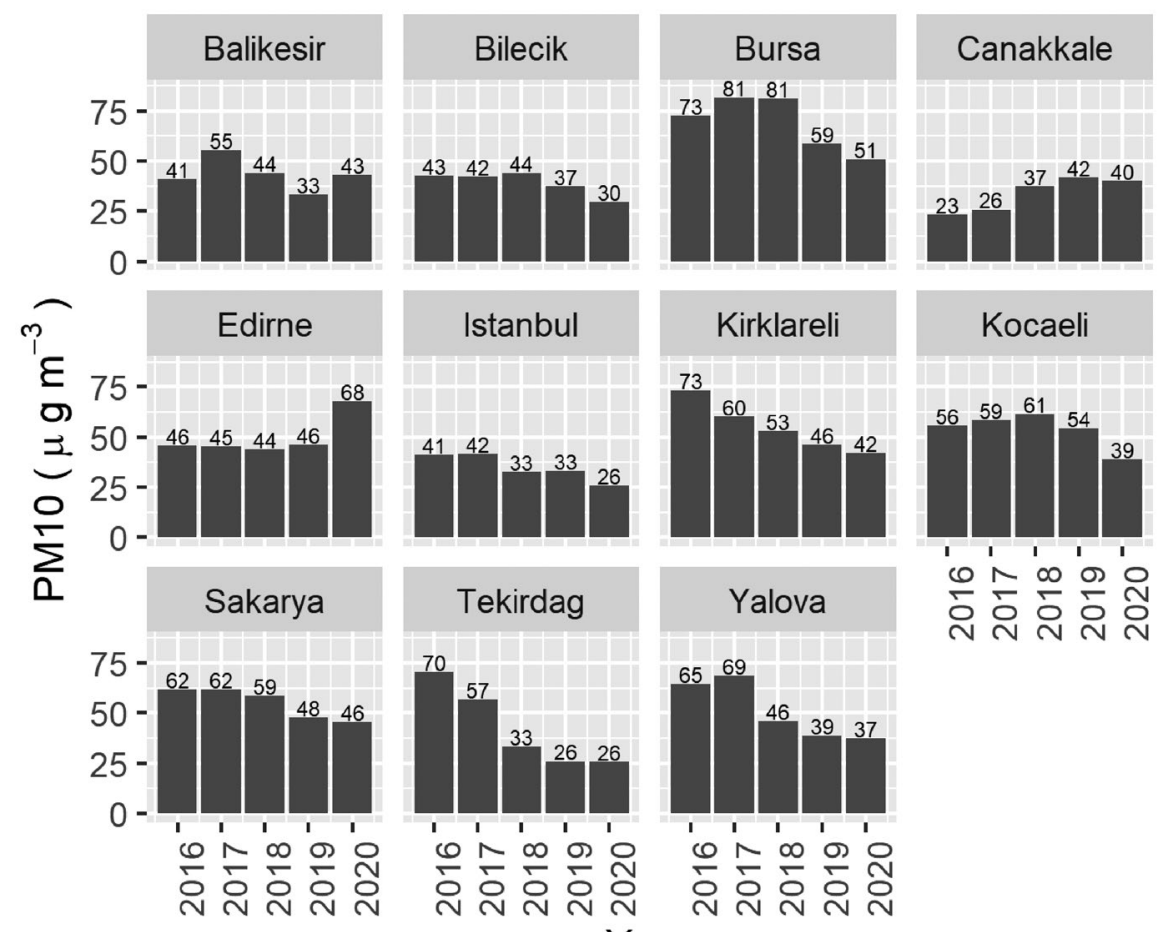
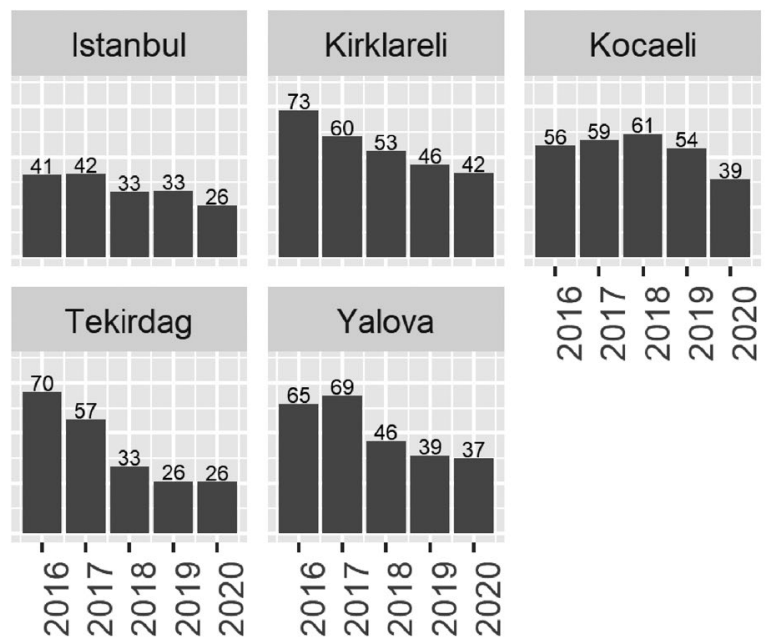

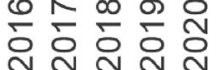


the other stations. They experienced increases during 2020 with respect to the long-term mean. The reason for the increase at Çanakkale is the replacement of the air quality station. The influence of dust transport at the Edirne station during the LDM can be seen in the rate of change.

The annual mean $\mathrm{PM}_{10}$ concentration for 2016-2020 for all the stations is seen in Fig. 3. As seen in Fig. 3, the annual mean $\mathrm{PM}_{10}$ concentration of 2020 is lower than the mean of the previous 4 years for all the stations except Balıkesir, Canakkale, and Edirne. The annual mean concentrations of $\mathrm{PM}_{10}$ of 2020 are the same for the previous 4 years for Balıkesir, while it is higher for Canakkale and Edirne. The annual mean $\mathrm{PM}_{10}$ concentration of 2020 is also lower than that of 2019 for all the stations, except Balıkesir, Edirne, and Tekirdag. Balıkesir and Edirne have higher $\mathrm{PM}_{10}$ concentrations in 2020 than in 2019, while Tekirdag has the same levels for 2 years.

$\mathrm{PM}_{2.5}$ concentration

The daily $\mathrm{PM}_{2.5}$ concentrations during the PLD, LDM, and ALD are shown in the time series located on the outer part of Fig. 4. The blue arrows indicate the decline of $\mathrm{PM}_{2.5}$ during the LDM and ALD with respect to PLD, while the red arrows indicate increases. As seen in Fig. 4, all the stations are experiencing a decline in PM2.5 concentrations during both the LDM and ALD periods. Although the PM10 analysis shows mixed results, it is not a good indicator to show the efficiency of the lockdown measures. $\mathrm{PM}_{10}$ is related to traffic emissions but mass measurement techniques do not always capture this influence (Kendrick et al., 2015). $\mathrm{PM}_{2.5}$ and $\mathrm{NO}_{2}$ are the key parameters

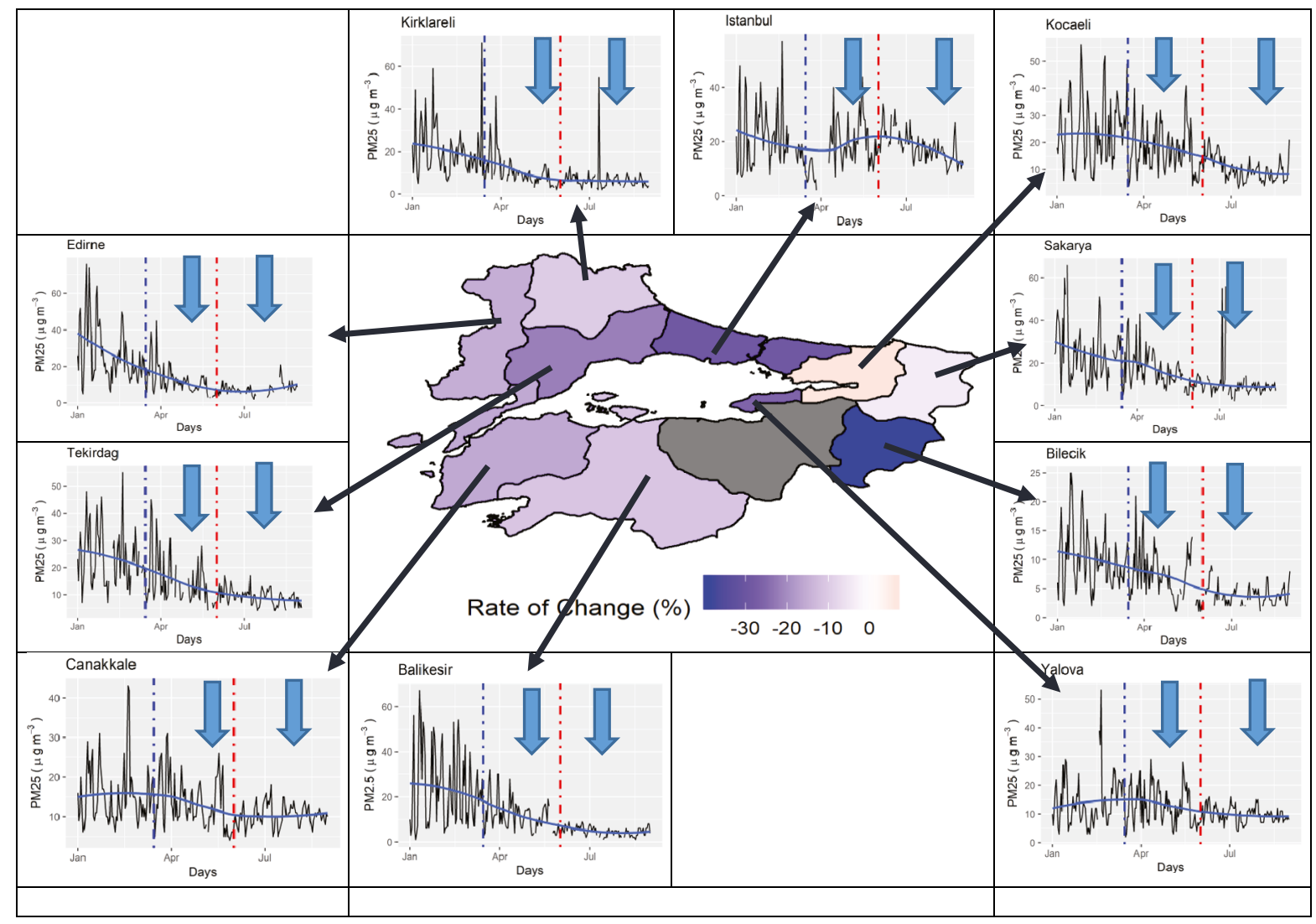

Fig. 4 (a) Time series located outer of the graph, represent the daily mean $\mathrm{PM}_{2.5}$ concentrations for the period of January 1August 31, 2020. (b) Inner map represents the change of mean
$\mathrm{PM}_{2.5}$ concentrations during $\mathrm{LDM}$ with respect to mean $\mathrm{PM}_{2.5}$ concentrations of the same period of the previous year. 
Table 6 As in Table 2, except for $\mathrm{PM}_{2.5}$

\begin{tabular}{llllcl}
\hline & $\begin{array}{l}\text { Average (PLD) } \\
\left(\mu \mathrm{g} / \mathrm{m}^{3}\right)\end{array}$ & $\begin{array}{l}\text { Average }(\mathrm{LDM}) \\
\left(\mu \mathrm{g} / \mathrm{m}^{3}\right)\end{array}$ & $\begin{array}{l}\text { Rate of } \\
\text { change }(\%)\end{array}$ & $\begin{array}{l}\text { Average (ALD) } \\
\left(\mu \mathrm{g} / \mathrm{m}^{3}\right)\end{array}$ & $\begin{array}{l}\text { Rate of } \\
\text { change } \\
(\%)\end{array}$ \\
\hline Balıkesir & 23.7 & 11.8 & -50 & 4.8 & -79 \\
Bilecik & 9.9 & 7.2 & -27 & 3.9 & -60 \\
Çanakkale & 15.4 & 13.5 & -12 & 10.4 & -32 \\
Edirne & 26.6 & 12.3 & -50 & 7.7 & -71 \\
İstanbul & 21.0 & 18.4 & -12 & 18.1 & -13 \\
Kirklareli & 20.0 & 10.4 & -48 & 6.7 & -66 \\
Kocaeli & 23.7 & 17.5 & -26 & 10.2 & -56 \\
Sakarya & 24.1 & 16.6 & -31 & 9.9 & -59 \\
Tekirdag & 23.6 & 15.0 & -36 & 9.1 & -61 \\
Yalova & 14.2 & 12.9 & -9 & 9.8 & -30 \\
\hline
\end{tabular}

for traffic-related pollution as it could be affected more than $\mathrm{PM}_{10}$ by these lockdown measures.

The rate of decrease in $\mathrm{PM}_{2.5}$ for all stations during the LDM with respect to PLD fluctuates between 9 (Yalova) and 50 (Balıkesir) percent (Table 6), with the region average of 30\%. Çanakkale, İstanbul and Yalova are the stations that experience smaller declines by 12,12 , and $9 \%$, respectively. Balıkesir, Edirne, and Kırklareli experienced the highest declines by 50, 50, and $48 \%$, respectively. The rate of change for each station is quite sensitive to the station location during the LDM. For example, the İstanbul station is located on one of the main roads of the city which is used by many vehicles outside for essential purposes. All the cities in the region showed decline during LDM with respect to PLD. Lian et al. (2020) found the similar result with the mean decline of $\mathrm{PM}_{2.5}$ about $20 \%$, for the stations in Wuhan City, China. On the other hand, Adams (2020) concluded that $\mathrm{PM}_{2.5}$ concentrations did not change significantly during lockdown measures, in the cities of Ontario, Canada. They emphasized that this result is related to the source profile of the stations.

All the stations experienced a decline during ALD with respect to PLD (Table 6). The decline rate varied between 13 (İstanbul) and 79 (Balıkesir) percent, with the region average of $53 \%$. İstanbul, Çanakkale, and Yalova have the smallest declines at 13, 32, and $30 \%$, respectively while Balıkesir, Edirne, and
Kurklareli have larger declines of 79,71 and $66 \%$. The rate of change during the ALD is greater than the rate of change during the LDM. Although the location dependency for the rate of change at each station is valid, the rate of change is almost doubled due to additional seasonal effects.

The exceedance number of $\mathrm{PM}_{2.5}$ limits during PLD and LDM is seen in Table 7. The number of exceedances in the region varies between 11 and 59 in the region with the mean of 41 days during PLD. During LDM, the exceedance numbers vary between 2 and 41 days with the average of 23 days. The average exceedance number of the region during LDM declined $44 \%$ with respect to PLD. All the stations experienced decline of exceedance numbers during LDM with respect to PLD. Maximum decline in exceedance number was observed in Bilecik with the value of $82 \%$.

The average concentrations of $\mathrm{PM}_{2.5}$ during the subLDM periods are seen in Table 8. All the stations experience declines of $\mathrm{PM}_{2.5}$ during FLD with respect to RDLM days, with the region average of $17 \%$. The decline rates vary between 5 and 30\%. İstanbul and Yalova are the stations with smaller declines, both locations at 5\%. Yalova is not a metropolitan city, so the decline is smaller. İstanbul is a constant pollution source of $\mathrm{PM}_{2.5}$. The highest decline values are observed at the Çanakkale and Kırklareli stations with 25 and $30 \%$, respectively. In small cities the
Table 7 As in Table 3, except for $\mathrm{PM}_{2.5}$ concentrations

\begin{tabular}{lllllllllll}
\hline & Balı & Bilec & Cana & Edir & İsta & Kırk & Koca & Saka & Teki & Yalo \\
\hline PLD & 45 & 11 & 29 & 59 & 43 & 44 & 50 & 51 & 51 & 28 \\
LDM & 17 & 2 & 27 & 14 & 37 & 11 & 41 & 35 & 21 & 25 \\
\hline
\end{tabular}


Table 8 The average $\mathrm{PM}_{2.5}$ concentrations during subLDM periods, FLD and RFLD, and change of mean $\mathrm{PM}_{2.5}$ concentrations during FLD with respect to RFLD

\begin{tabular}{lcll}
\hline & $\begin{array}{l}\text { Average (FLD) } \\
\left(\mu \mathrm{g} / \mathrm{m}^{3}\right)\end{array}$ & $\begin{array}{l}\text { Average (RFLD) } \\
\left(\mu \mathrm{g} / \mathrm{m}^{3}\right)\end{array}$ & $\begin{array}{l}\text { Rate of } \\
\text { change } \\
(\%)\end{array}$ \\
\hline Balıkesir & 10.1 & 12.2 & -17 \\
Bilecik & 5.9 & 7.5 & -21 \\
Çanakkale & 10.7 & 14.2 & -25 \\
Edirne & 10.5 & 12.7 & -17 \\
İstanbul & 17.7 & 18.6 & -5 \\
Kirklareli & 7.7 & 11.1 & -30 \\
Kocaeli & 15.3 & 18.1 & -15 \\
Sakarya & 14.3 & 17.2 & -17 \\
Tekirdag & 13.2 & 15.2 & -13 \\
Yalova & 12.4 & 13.0 & -5 \\
\hline
\end{tabular}

people obey the lock-down measures spontaneously, and this result is seen in the air quality measurements. Even though, there is no decline in workplace mobility, the cause of decline in $\mathrm{PM}_{2.5}$ can be the decline in other mobility types.

Lastly, the change rate for the mean $\mathrm{PM}_{2.5}$ concentration during the LDM with respect to the mean $\mathrm{PM}_{2.5}$ concentrations during the same period for the
Table 9 Average $\mathrm{PM}_{2.5}$ concentrations during LDM and the same period of the previous year and the change of concentrations during LDM with respect to the previous year

\begin{tabular}{lcll}
\hline & $\begin{array}{l}\text { Average LDM } \\
\left.\mu \mathrm{g} / \mathrm{m}^{3}\right)(2020)\end{array}$ & $\begin{array}{l}\text { Previous year average } \\
\text { of same period }(\mu \mathrm{g} / \\
\left.\mathrm{m}^{3}\right)\end{array}$ & $\begin{array}{l}\text { Rate of } \\
\text { change } \\
(\%)\end{array}$ \\
\hline Balıkesir & 11.8 & 13.2 & -11 \\
Bilecik & 7.2 & 11.8 & -39 \\
Çanakkale & 13.5 & 16.0 & -16 \\
Edirne & 12.3 & 14.4 & -15 \\
İstanbul & 18.4 & 26.0 & -29 \\
Kirklareli & 10.4 & 11.6 & -10 \\
Kocaeli & 17.5 & 16.5 & +6 \\
Sakarya & 16.6 & 17.9 & -4 \\
Tekirdag & 15.0 & 19.2 & -22 \\
Yalova & 12.9 & 17.5 & -26 \\
\hline
\end{tabular}

previous year (2019) are investigated. All the stations except Kocaeli experienced a decline during the LDM (Table 9), with the region average of $16.5 \%$ decrease. The decline rates fluctuate between 4 and $39 \%$. Kurklareli and Sakarya are the stations with the smallest decline at 10 and $4 \%$, respectively, while Bilecik and İstanbul experienced the greatest declines of 39 and 29\%, respectively. Kocaeli exhibited different
Fig. 5 The annual mean concentrations of $\mathrm{PM}_{2.5}$
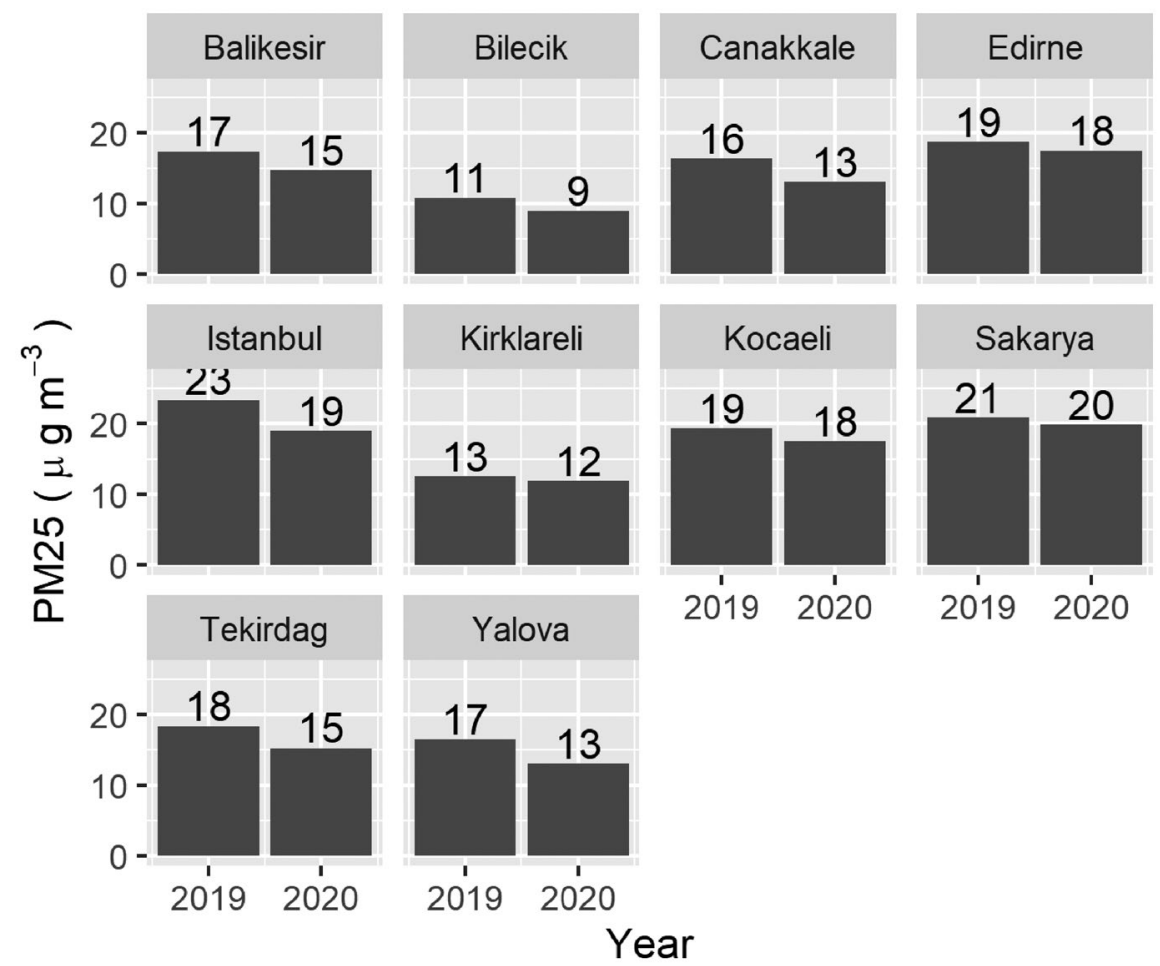


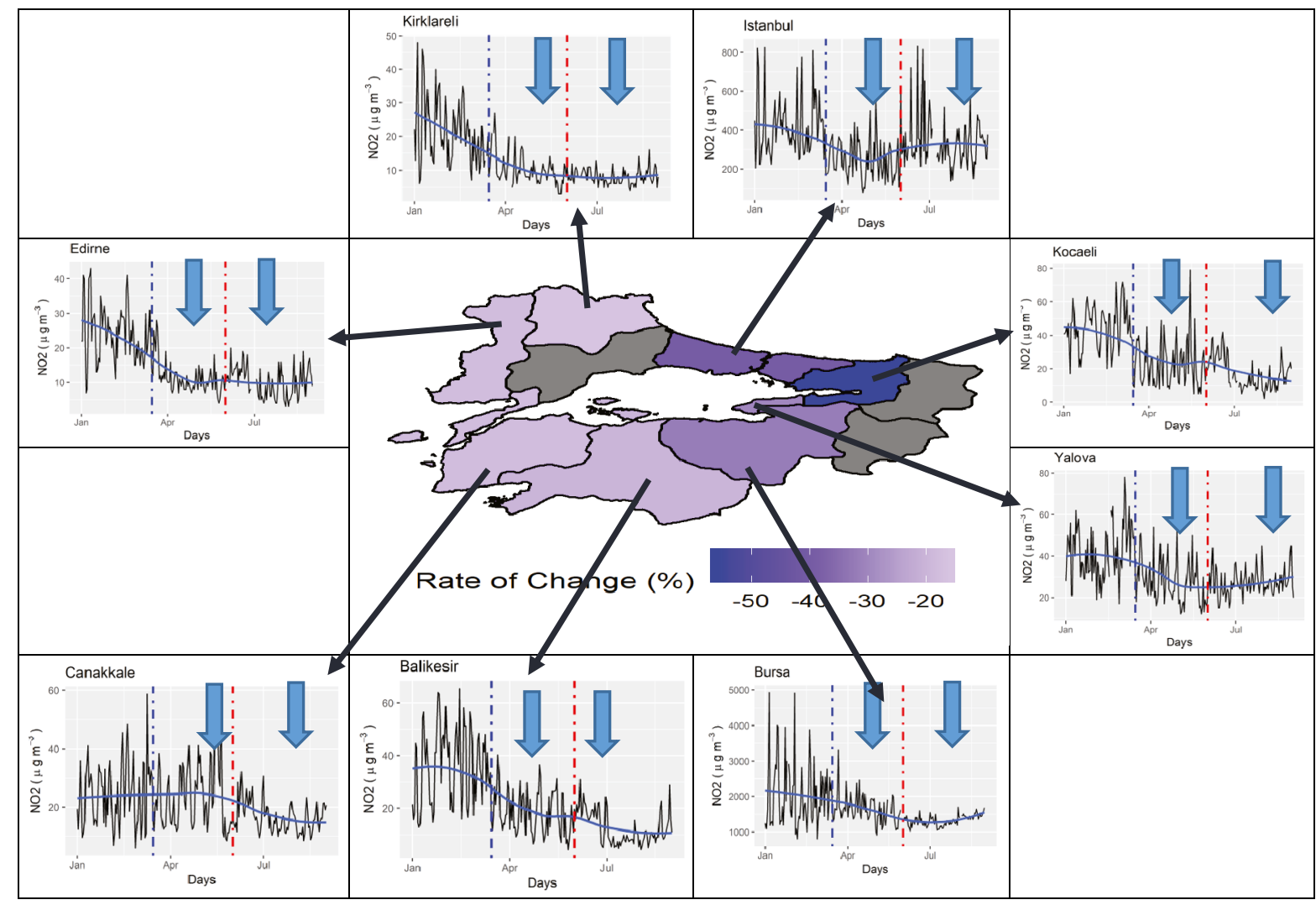

Fig. 6 Same in Fig. 3, except for $\mathrm{NO}_{2}$

behaviors than other stations as $\mathrm{PM}_{2.5}$ increased during 2020 with respect to the same period in 2019 at $6 \%$.

The annual mean $\mathrm{PM}_{2.5}$ concentration for 2019-2020 for all the stations is seen in Fig. 5. As seen in Fig. 5, the annual mean $\mathrm{PM}_{2.5}$ concentration of 2020 is lower than the mean of 2019 for all the stations. The lowest decline belongs to the Sakarya station with the value of 5\%, while the highest belongs to the Yalova station with the value of $24 \%$.
$\mathrm{NO}_{2}$ concentrations

The daily $\mathrm{NO}_{2}$ concentrations for PLD, LDM, and after-lockdown ALD are shown in the time series located on the outer part of Fig. 6. The blue arrows indicate a decline during the LDM and ALD with respect to PLD, while the red arrows indicate increases. As seen in Fig. 6, all the cities experience
Table 10 As in Table 2, except for $\mathrm{NO}_{2}$

\begin{tabular}{llllll}
\hline & $\begin{array}{l}\text { Average (PLD) } \\
\left(\mu \mathrm{g} / \mathrm{m}^{3}\right)\end{array}$ & $\begin{array}{l}\text { Average (LDM) } \\
\left(\mu \mathrm{g} / \mathrm{m}^{3}\right)\end{array}$ & $\begin{array}{l}\text { Rate of } \\
\text { change }(\%)\end{array}$ & $\begin{array}{l}\text { Average (ALD) } \\
\left(\mu \mathrm{g} / \mathrm{m}^{3}\right)\end{array}$ & $\begin{array}{l}\text { Rate of } \\
\text { change } \\
(\%)\end{array}$ \\
\hline Balıkesir & 35.2 & 17.8 & -49 & 12.0 & -65 \\
Bursa & 72.2 & 51.0 & -29 & 43.8 & -39 \\
Çanakkale & 23.9 & 23.5 & -1 & 16.1 & -32 \\
Edirne & 23.9 & 11.2 & -53 & 10.2 & -59 \\
İstanbul & 73.3 & 46.4 & -37 & 51.7 & -31 \\
Kurklareli & 21.2 & 10.1 & -52 & 8.1 & -62 \\
Kocaeli & 43.8 & 23.2 & -47 & 17.1 & -61 \\
Yalova & 41.3 & 27.6 & -33 & 27.1 & -34 \\
\hline
\end{tabular}


Table 11 As in Table 3, except for $\mathrm{NO}_{2}$

\begin{tabular}{lllllllll}
\hline & Balı & Bursa & Cana & Edir & İsta & Kırk & Koca & Yalo \\
\hline PLD & 50 & 74 & 35 & 30 & 56 & 19 & 69 & 68 \\
LDM & 16 & 65 & 31 & 2 & 62 & 1 & 31 & 39 \\
\hline
\end{tabular}

a decline of $\mathrm{NO}_{2}$ concentrations during both the LDM and ALD periods that is consistent with Lian et al. (2020), Adams (2020), and further studies. Lian et al. (2020) found a decrease of 53\% for the cities in Hubei province, China, and Adams found a significant evidence for decline of nitrogen dioxide and nitrogen oxides for the stations in Ontario, Canada.

The rate of decrease for all the stations during the LDM with respect to PLD fluctuates between 29 (Bursa) and 53 (Edirne) percent except for the Çanakkale station (Table 10). The Çanakkale station experienced only a decline of $1 \%$, with the region average of 38\%. Bursa and Yalova are the stations that experience smaller declines at 29 and 33\%, respectively. The Edirne and Kurklareli stations observe larger decreases of 53 and $52 \%$, respectively.

The significant decreases were observed during the ALD, as seen in Fig. 4 and Table 10 in the range of 31 (İstanbul) and 65 (Balıkesir), with the region average of $48 \%$. Four of the nine $\mathrm{NO}_{2}$ stations experienced declines between 31 and $39 \%$, while others experienced more than $59 \%$.

The exceedance number of $\mathrm{NO}_{2}$ limits during PLD and LDM is seen in Table 11. The number of exceedances in the region varies between 19 and 74 in the region with the mean of 50 days during PLD. During LDM, the exceedance numbers vary between 1 to 65 days with the average of 30 days. The average exceedance number of the region during LDM declined 53\% with respect to PLD. There is also an increment in exceedance numbers in only one station. İstanbul observed the maximum increment during LDM with respect to PLD with the value of $11 \%$. Maximum decline in exceedance number was observed in Kurklareli with the value of $93 \%$.

The average concentrations of $\mathrm{NO}_{2}$ during the subLDM periods are seen in Table 12. All the stations experience declines in $\mathrm{NO}_{2}$ during FLD with respect to RDLM days, with the average of $27 \%$. The decline rates vary between 4 (Çanakkale) and 42 (Bursa) percent. Çanakkale and Yalova are the stations with smaller declines at 4 and 20\%, respectively. As stated above, these cities are not metropolitan cities, which resulted in smaller declines. Higher declines are observed at the Bursa and Kocaeli stations, 42 and $39 \%$, respectively. These stations are traffic-heavy stations, and the full lockdown led to the decrease of the traffic emissions in these cities.

Lastly, the change in the mean $\mathrm{NO}_{2}$ concentration during the LDM with respect to the mean $\mathrm{NO}_{2}$ concentrations during the same period of the previous year (2019) are investigated. All the stations experienced a decline during the LDM (Table 13). The declines varied between 16 and $56 \%$, with the average of $29 \%$. Çanakkale and Kırklareli are the stations with the smallest declines of 16 and $18 \%$, respectively, while İstanbul and Kocaeli experience the largest declines at 40 and 56\%, respectively. The

Table 12 As in Table 8, except for $\mathrm{NO}_{2}$

\begin{tabular}{|c|c|c|c|c|c|c|}
\hline & $\begin{array}{l}\text { Average (FLD) } \\
\left(\mu \mathrm{g} / \mathrm{m}^{3}\right)\end{array}$ & $\begin{array}{l}\text { Average } \\
\left(\text { RFLD) }\left(\mu \mathrm{g} / \mathrm{m}^{3}\right)\right.\end{array}$ & $\begin{array}{l}\text { Rate of } \\
\text { change }(\%)\end{array}$ & $\begin{array}{l}\text { Average LDM } \\
\left(\mu \mathrm{g} / \mathrm{m}^{3}\right)\end{array}$ & $\begin{array}{l}\text { Previous year average of } \\
\text { same period }\left(\mu \mathrm{g} / \mathrm{m}^{3}\right)\end{array}$ & $\begin{array}{l}\text { Rate of } \\
\text { change } \\
(\%)\end{array}$ \\
\hline Balıkesir & 13.1 & 19.0 & -31 & 17.8 & 22.2 & -20 \\
\hline Bursa & 32.3 & 56.0 & -42 & 51.0 & 74.9 & -32 \\
\hline Çanakkale & 22.7 & 23.7 & -4 & 23.5 & 28.6 & -18 \\
\hline Edirne & 8.1 & 11.9 & -32 & 11.2 & 13.7 & -18 \\
\hline İstanbul & 34.7 & 49.3 & -24 & 46.4 & 77.3 & -40 \\
\hline Kırklareli & 7.5 & 10.7 & -30 & 10.1 & 12.1 & -16 \\
\hline Kocaeli & 15.3 & 25.1 & -39 & 23.2 & 53.1 & -56 \\
\hline Yalova & 23.1 & 28.7 & -20 & 27.6 & 39.4 & -30 \\
\hline
\end{tabular}


Table 13 As in Table 9, except for $\mathrm{NO}_{2}$

\begin{tabular}{llll}
\hline & $\begin{array}{l}\text { Average } \\
\text { LDM }(\mu \mathrm{g} / \\
\left.\mathrm{m}^{3}\right)\end{array}$ & $\begin{array}{l}\text { Previous year average } \\
\text { of same period }\left(\mu \mathrm{g} / \mathrm{m}^{3}\right)\end{array}$ & $\begin{array}{l}\text { Rate of } \\
\text { change } \\
(\%)\end{array}$ \\
\hline Balıkesir & 17.8 & 22.2 & -20 \\
Bursa & 51.0 & 74.9 & -32 \\
Çanakkale & 23.5 & 28.6 & -18 \\
Edirne & 11.2 & 13.7 & -18 \\
İstanbul & 46.4 & 77.3 & -40 \\
Kirklareli & 10.1 & 12.1 & -16 \\
Kocaeli & 23.2 & 53.1 & -56 \\
Yalova & 27.6 & 39.4 & -30 \\
\hline
\end{tabular}

same patterns as discussed above are the explanation for these results. Less crowded cities demonstrated lower declines because full lockdown measures were not undertaken in them. On the other hand, more crowded cities experienced higher declines due to the full lockdown measures.

The annual mean $\mathrm{NO}_{2}$ concentration for 2019-2020 for all the stations is seen in Fig. 7. As seen in Fig. 7, the annual mean $\mathrm{NO}_{2}$ concentration of 2020 is lower than the mean of 2019 for all the stations, except Balıkesir and Kırklareli. The $\mathrm{NO}_{2}$ level increased in
2020 compared to 2019 with the value of 5 and $7 \%$ for Balıkesir and Kırklareli, respectively. The highest declines are observed in the large cities. Bursa, İstanbul, and Kocaeli have the highest decline rates with the values of 16,16 , and $47 \%$, respectively.

Mobility data

The time series of the mobility data and daily average $\mathrm{PM}_{10}, \mathrm{PM}_{2.5}$, and $\mathrm{NO}_{2}$ concentrations for each of the cities during the LDM period are seen in Fig. 8.

As seen in Fig. 8, the higher the population, the greater the decrease in mobility. The peak values in the figures for the metropolitan cities are seen during the full lockdown (FLD) days. The last peak value that can be seen in all the cities was occurred during the lockdown which was applied for the whole country. There are declines in the mean concentrations of all pollutants at different levels for all the stations during these peaks.

Figure 8 shows an important change in work mobility after the lockdown measures were implemented. Overall average of work mobility decline during LDM for each city is around 50\%. It can be seen from Fig. 8 the decline of $\mathrm{NO}_{2}$ increases when FLD measures are applied in metropolitan cities. On
Fig. 7 The annual mean concentrations of $\mathrm{NO}_{2}$

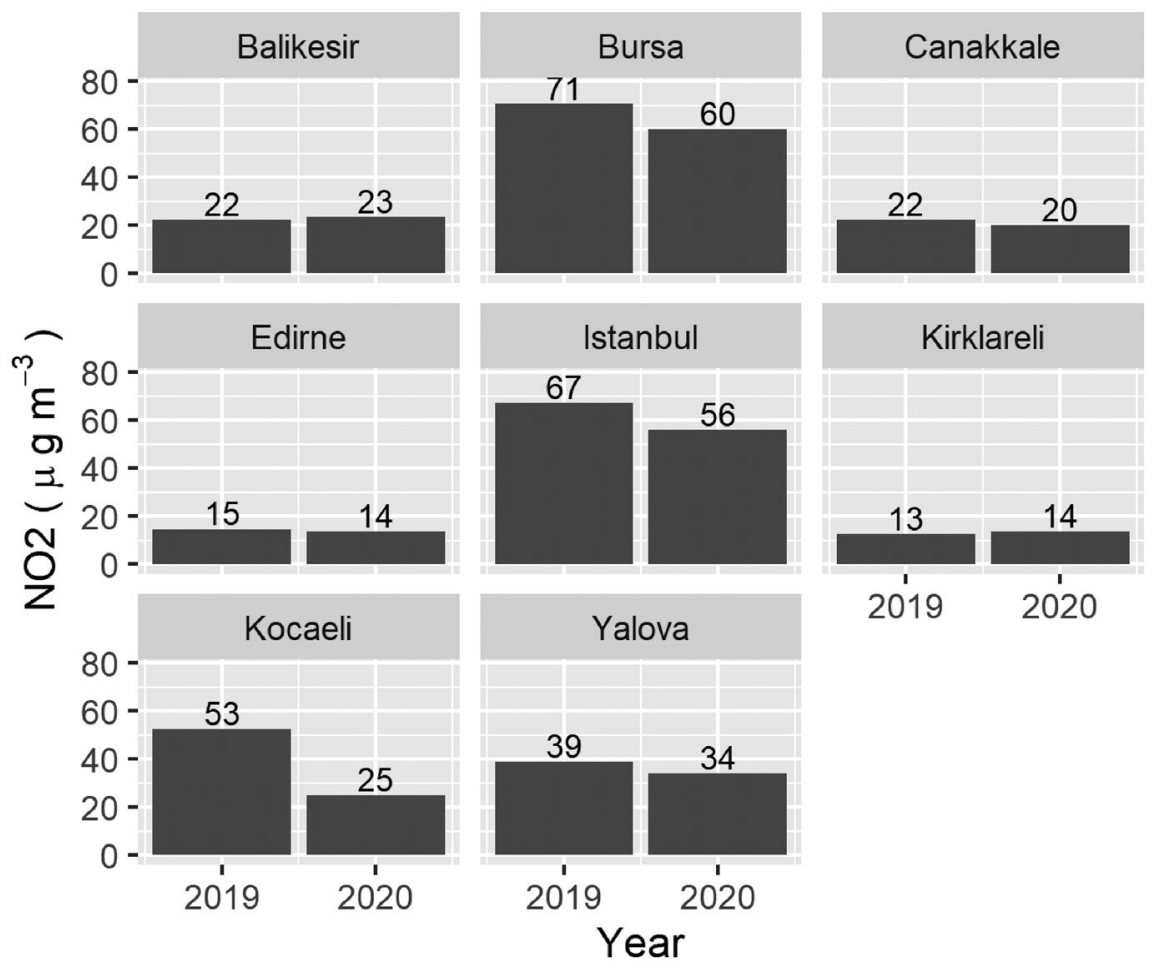


Fig. 8 Time series of the mobility during the LDM with respect to 1 January-16 February 2020 for the stations used in this study (negative values in y axis; yellow mobility lines represent the mobility change for Istanbul and Bursa by Apple (AMC represents Apple mobility change); brown mobility lines represent the mobility change for all the stations (GMC represents Google mobility change); black line represents the average mobility change during LDM period) and $\mathrm{PM}_{10}$ (red), $\mathrm{PM}_{2.5}$ (green), and $\mathrm{NO}_{2}$ (blue) concentrations during LDM (positive values)

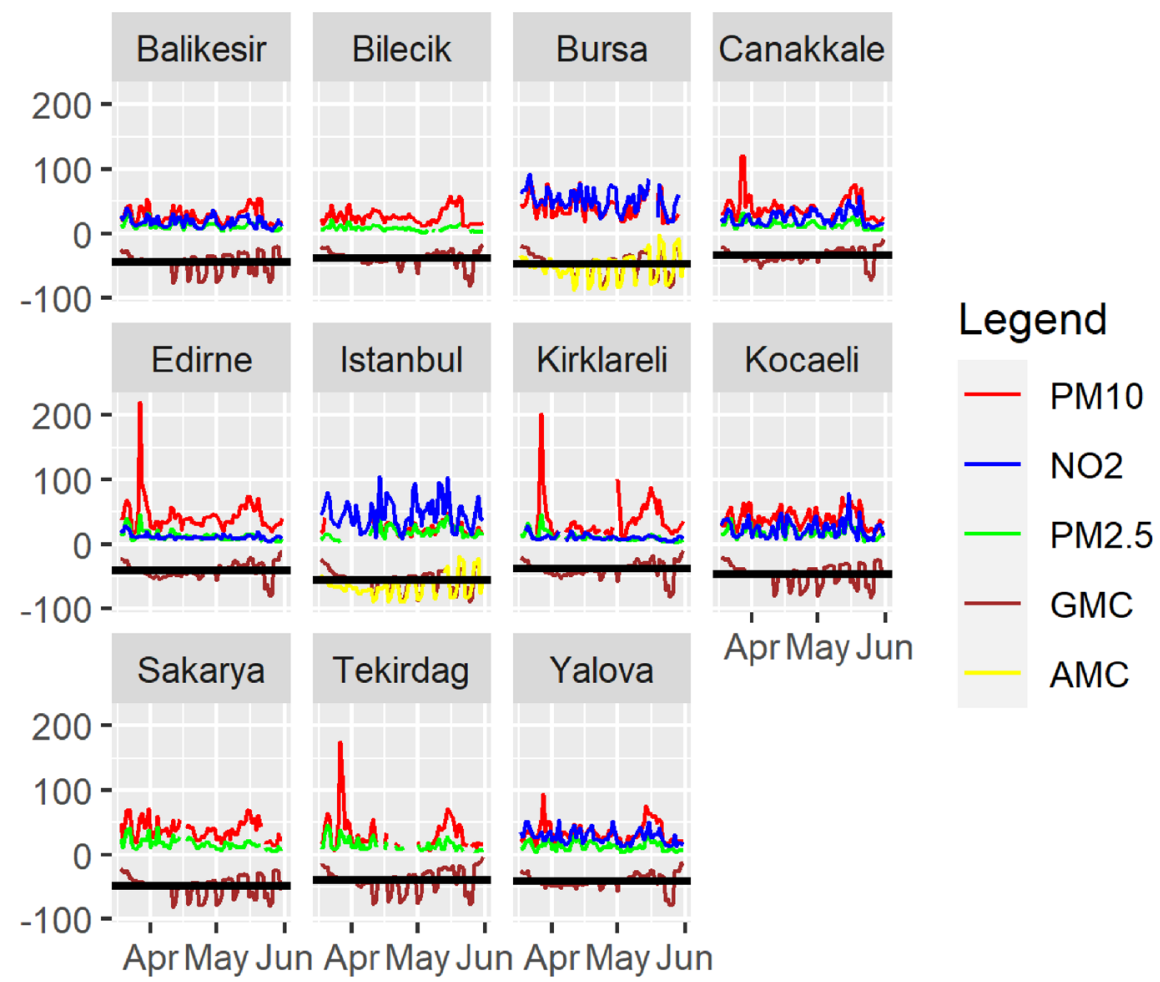

Date the other hand, $\mathrm{PM}_{10}$ and $\mathrm{PM}_{2.5}$ concentrations do not respond to the mobility declines. The daily mean number of cars for a location in Istanbul is 6250 and 3750 for the period before PLD and FLD, respectively. The decline in the vehicle numbers is $40 \%$ which is almost identical to the decline in the Google mobility data of Istanbul.

The correlations between mobility change and pollutant concentrations were calculated and tested via Pearson's test, and the results are shown in Table 14.
The correlation coefficient between mobility and $\mathrm{PM}_{10}$ varies between 0.12 (Kocaeli) and 0.30 (Bursa). None of the correlation coefficient is statistically significant. The correlation coefficients between Apple mobility data and $\mathrm{PM}_{10}$ concentration are 0.27 and 0.19 for Bursa and Istanbul, respectively, and they are not statistically significant. The correlation coefficients between mobility and $\mathrm{PM}_{2.5}$ vary between 0.04 (Edirne) and 0.12 (Canakkale). None of the correlation coefficient is statistically significant. The

Table 14 Pearson's correlation coefficients between work mobility dec and pollutant concentrations

\begin{tabular}{|c|c|c|c|c|c|c|c|c|c|c|c|}
\hline $\begin{array}{l}\text { Correlation } \\
\text { coefficient }\end{array}$ & Balıkesir & Bilecik & Bursa & Canakkale & Edirne & İstanbul & Kırklareli & Kocaeli & Sakarya & Tekirda $\breve{g}$ & Yalova \\
\hline $\mathrm{PM}_{10}$ & 0.13 & 0.19 & $\begin{array}{l}0.30 \\
(0.27)\end{array}$ & 0.13 & 0.17 & $\begin{array}{l}0.28 \\
(0.19)\end{array}$ & 0.19 & 0.12 & 0.21 & 0.14 & 0.15 \\
\hline $\mathrm{PM}_{2.5}$ & 0.06 & 0.08 & - & 0.12 & 0.04 & $\begin{array}{l}-0.07 \\
(0.03)\end{array}$ & 0.07 & 0.11 & 0.09 & 0.01 & 0.06 \\
\hline $\mathrm{NO}_{2}$ & $0.40 * *$ & - & $\begin{array}{l}0.64 * * \\
(0.54 * *)\end{array}$ & 0.29 & $0.38 * *$ & $\begin{array}{l}0.45 * * \\
(0.40)^{* *}\end{array}$ & $0.30 * *$ & $0.47 * *$ & - & - & $0.25 *$ \\
\hline
\end{tabular}

$N S$ denotes two samples are not significant correlated $(p \geq 0.05)$. The values in the parentheses for Istanbul and Bursa are the correlation coefficients between driving mobility provided by Apple and pollutant concentrations

*denotes correlations between two samples are significant at the levels of $0.001 \leq p<0.01$

$* *$ denotes correlations between two samples are significant at the levels of $p<0.001$ 
correlation coefficient between Apple data and $\mathrm{PM}_{2.5}$ concentration is 0.03 for Istanbul. All the correlation coefficients between mobility changes and both $\mathrm{PM}_{10}$ and $\mathrm{PM}_{2.5}$ are smaller than 0.30 , and they are not statistically significant for all the stations which means there is no correlation between mobility and $\mathrm{PM}_{10}$ and $\mathrm{PM}_{2.5}$. On the other hand, $\mathrm{NO}_{2}$ is highly correlated to mobility compared to $\mathrm{PM}_{10}$ and $\mathrm{PM}_{2.5}$. Correlation coefficients vary between 0.25 and 0.64 . Yalova and Canakkale have lower correlation coefficients which vary between 0.25 and 0.64 . Yalova and Canakkale have lower correlation coefficients of 0.25 and 0.29, respectively. Bursa and Kocaeli have higher correlation coefficients of 0.64 and 0.47 , respectively. The correlation coefficient between the Apple data and $\mathrm{NO}_{2}$ concentration in Bursa and İstanbul are 0.54 and 0.40 , respectively, which are statistically significant. All the correlation coefficients greater than 0.30 are statistically significant, $p$-value greater than 0.001 , while the correlation coefficient of Yalova is statistically significant with a $p$-value greater than 0.01 . The correlation coefficient of Çanakkale is not significant. In general, large cities have a greater correlation coefficient than the small cities.

\section{Conclusion}

The outbreak of the novel coronavirus (COVID-19) has changed the daily routines of people around the world. The first case was confirmed in Turkey on 11 March 2020. The relevant authorities first shut down airway transportation and, then the borders. The schools are closed and online education started. Stay-at-home orders, social distance measures and lockdown measures were applied. However, in spite of these measures, the number of cases reached 4500 per day by 10 April. Since then, the government announced that in cities from 10 April to June 1, more restrictive measures will be imposed on 31 major cities. The change in concentrations of $\mathrm{PM}_{10}, \mathrm{PM}_{2.5}$, and $\mathrm{NO}_{2}$ during these measures with respect to the pre-lockdown period, the same period in the previous years and for different levels of measures for the cities in Marmara Region of Turkey were investigated in this study. The daily mean concentrations of $\mathrm{PM}_{10}, \mathrm{PM}_{2.5}$, and $\mathrm{NO}_{2}$ obtained from 11 stations operated by the Ministry of Environment and Urbanization and Google mobility data are used in this study. The main findings are listed below:
1. Eight of the 11 stations experienced decline of average $\mathrm{PM}_{10}$ concentrations during the lockdown period compared to the pre-lockdown period with a change rate between 14 and 30\%. Similarly, the average $\mathrm{PM}_{10}$ concentrations after lockdown decreased with respect to the pre-lockdown in 8 of the 11 stations (not the same stations). The strict lockdown measures decreased the $\mathrm{PM}_{10}$ levels in all the stations. Nine of the 11 stations experienced decline in the lockdown period with respect to the average of the same period in the previous 4 years with varying ratios of 29 to $51 \%$.

2. $\mathrm{PM}_{2.5}$ concentrations in all the stations decreased during lockdown measures with respect to the pre-lockdown with the rate of 9 to $50 \%$. During the after-lockdown period, decline values varied between 13 and $79 \%$ with an increase in one station. $\mathrm{PM}_{2.5}$ concentrations decreased with district measures with varying rates between 5 and $30 \%$. The decrease in concentrations of $\mathrm{PM}_{2.5}$ during the lockdown measures with respect to the previous year vary between -4 and $39 \%$, except Kocaeli. It experienced increment with the rate of $6 \%$.

3. All the stations experienced decline of $\mathrm{NO}_{2}$ concentrations during the lockdown-measure period and after-lockdown period with respect to the pre-lockdown period. The rates vary between 1 and 53\% during lockdown and 31 to $65 \%$ during the after lockdown. District measures affected $\mathrm{NO}_{2}$ concentrations as well. $\mathrm{NO}_{2}$ concentrations decreased in all the stations at a varying rate of 4 to $42 \%$. The decrease in the concentrations of $\mathrm{NO}_{2}$ with respect to the previous year varies between 16 and $56 \%$.

4. No correlation emerged between mobility and both $\mathrm{PM}_{10}$ and $\mathrm{PM}_{2.5}$ for none of the cities. On the other hand, the correlation coefficients between mobility reduction and $\mathrm{NO}_{2}$ concentration vary between 0.25 and 0.64 . All the correlation coefficients greater than 0.30 are statistically significant with a $p$-value greater than 0.001 . Apple data gave similar results for Bursa and Istanbul.

Acknowledgements The author is grateful to the Marmara Clean Air Center (10 stations) and Greater Istanbul Municipality for providing air pollution data, for Y. Burak Öztaner for 
encouraging the author to write this paper and help for every stage, Dr. Anthony Lupo and Ozkan Çapraz for providing language help, for Dr. Selahattin Incecik for proof reading the article and referees for their useful comments and suggestions that have helped us improve the earlier version of the manuscript.

Data availability The datasets used and/or analyzed during the current study are available from the corresponding author on reasonable request.

\section{Declarations}

Conflict of interest The author declares no competing interests.

\section{References}

Adams, M. D. (2020). Air pollution in Ontario, Canada during the COVID-19 state of emergency. Science of the Total Environment, 742(2020), 140516. https://doi.org/10. 1016/j.scitotenv.2020.140516

Agacayak, T., Kindap, T., Unal, A., Pozzoli, L., Mallet, M. \& Solmon, F. (2015). A case study for Saharan dust transport over Turkey via RegCM4.1 model. Atmospheric Research, 153 (2015), 392-403. https://doi.org/10.1016/j.atmosres. 2014.09.012

Baldasano, J. M. (2020). COVID-19 lockdown effects on air quality by $\mathrm{NO}_{2}$ in the cities of Barcelona and Madrid (Spain). Science of the Total Environment, 741(2020), 140353. https://doi.org/10.1016/j.scitotenv.2020.140353

Baltaci, H. (2017). Spatial and temporal variation of the extreme Saharan Dust event over Turkey in March 2016. Atmosphere, 8, 41. https://doi.org/10.3390/atmos8020041

Benesty, J., Chen. J, Huang, Y. \& Cohen, I. (2009) Pearson correlation coefficient. In: Noise reduction in speech processing. Springer Topics in Signal Processing, vol 2. Springer, Berlin, Heidelberg. https://doi.org/10.1007/978-3-642-00296-0_5

Çapraz, Ö., Efe, B., \& Deniz, A. (2016). Study on the association between air pollution and mortality in İstanbul, 20072012. Atmospheric Pollution Research, 7(2016), 147-154.

Chu, B., Zhang, S., Liu, J., Ma, Q. \& He, H. (2020) Significant concurrent decrease in $\mathrm{PM}_{2.5}$ and $\mathrm{NO}_{2}$ concentrations in China during COVID-19 epidemic. Journal of Environmental Sciences, 99(2020) ppb. 346 - 353. https://doi.org/ 10.1016/j.jes.2020.06.031

Collivignarelli, M. C., Abbà, A., Bertanza, G., Pedrazzani, R., Ricciardi, P., Miino, M. C. (2020) Lockdown for CoViD2019 in Milan: What are the effects on air quality? Science of The Total Environment, 139280.

Dantas, G., Siciliano, B., França, B. B., Silva, C. M., Arbilla, G. (2020). The impact of COVID-19 partial lockdown on the air quality of the city of Rio de Janeiro, Brazil. Science of The Total Environment, 729(2020), 139085.

Demirarslan, K , Akınc1, H. (2018). Assessment of winter season air quality in the Marmara Region using GIS and air quality data (in Turkish). Journal of Natural Hazards and
Environment, 4 (1), 11-27. https://doi.org/10.21324/dacd. 344564

Google. (2020). COVID-19 community mobility reports. https:// www.google.com/covid19/mobility/?hl=en-GB received date: 20.12.2020

Google Earth V 7.3.3.7786. (2021). The location of the stations used in the study. Basarsoft 2012. http://www.earth. google.com , received date February 10, 2021.

Greater Istanbul Municipality. (2020). Open data portal, https://data.ibb.gov.tr/en/dataset/3ee6d744-5da2-40c89cd6-0e3e41f1928f/resource/db9c7fb3-e7f9-435a-92f41b917e357821/download/traffic_density_202001.csv, received date February 10, 2022.

Hashim B. M., Al-Naseri S. K., Al-Maliki A., Al-Ansari, N. (2021). Impact of COVID-19 lockdown on $\mathrm{NO}_{2}, \mathrm{O}_{3}$, $\mathrm{PM}_{2.5}$ and $\mathrm{PM}_{10}$ concentrations and assessing air quality changes in Baghdad, Iraq. Science of The Total Environment, 754:141978. https://doi.org/10.1016/j.scitotenv.2020. 141978

Im, U., Markakis, K., Unal, A., Kindap, T., Poupkou, A., Incecik, S., Yenigun, O., Melas, D., Theodosi, C., \& Mihalopoulos, N. (2010). Study of a winter PM episode in Istanbul using high resolution WRF/CMAQ modeling system. Atmospheric Environment, 44(2010), 3085-3094.

Kabatas, B., Pierce, R. B., Unal, A., Rogal, M. J., \& Lenzen, A. (2018). April 2008 Saharan dust event: Its contribution to $\mathrm{PM}_{10}$ concentrations over the Anatolian Peninsula and relation with synoptic conditions. Science of the Total Environment, 633(2018), 317-328. https://doi.org/10. 1016/j.scitotenv.2018.03.150

Kahya, C., Balcik, F. B., Oztaner, Y. B., Ozcomak, D. \& Seker, D. Z. (2017). Spatio - Temporal Analysis of PM $_{2.5}$ over Marmara Region, Turkey. Fresenius Environmental Bulletin, 26(1), $310-317$.

Kasparoglu, S., Incecik, S., \& Topcu, H. S. (2018). Spatial and temporal variation of $\mathrm{O}_{3}, \mathrm{NO}$ and $\mathrm{NO}_{2}$ concentrations at rural and urban sites in Marmara Region of Turkey. Atmospheric Pollution Research, 9(6), 1009-1020. https:// doi.org/10.1016/j.apr.2018.03.005

Kendrick, C. M., Koonce, P., \& George, L. A. (2015). Diurnal and seasonal variations of $\mathrm{NO}, \mathrm{NO} 2$ and $\mathrm{PM}_{2.5}$ mass as a function of traffic volumes alongside an urban arterial. Atmospheric Environment, 122, 133-141. https://doi.org/ 10.1016/j.atmosenv.2015.09.019

Li, J., \& Tartarini, F. (2020). Changes in air quality during the COVID-19 lockdown in Singapore and associations with human mobility trends. Aerosol and Air Quality Research, 20, 1748-1758.

Lian, X., Huang, J., Huang, R., Liu, C., Wang, L., \& Zhang, T. (2020). Impact of city lockdown on the air quality of COVID-19-hit of Wuhan city. Science of the Total Environment, 742(2020), 140556. https://doi.org/10.1016/j. scitotenv.2020.140556

Menut, L., Bessagnet, B., Siour, G., Mailler, S., Pennel, R., \& Cholakian, A. (2020). (2020) Impact of lockdown measures to combat Covid-19 on air quality over western Europe. Science of the Total Environment, 741, 140426. https://doi.org/10.1016/j.scitotenv.2020.140426

Nakada, L. Y. K., \& Urban, R. C. (2020). COVID-19 pandemic: Impacts on the air quality during the partial 
lockdown in São Paulo State Brazil. Science of the Total Environment, 2020(730).

Otmani, A., Benchrif, A., Tahri, M., Bounakhla, M., Chakir, E. M., El Bouch, M., \& Krombi, M. (2020). Impact of Covid19 lockdown on $\mathrm{PM}_{10}, \mathrm{SO}_{2}$ and $\mathrm{NO}_{2}$ concentrations in Salé City (Morocco). Science of Total Environment, 735(2020), 139541. https://doi.org/10.1016/j.scitotenv.2020.139541

R Core Team. (2018). R: A language and environment for statistical computing. R Foundation for Statistical Computing.

Rodríguez-Urrego, D. \& Rodríguez-Urrego, L. (2020) Air quality during the COVID-19: $\mathrm{PM}_{2.5}$ analysis in the 50 most polluted capital cities in the world. Environmental Pollution, 266(1), 115042. https://doi.org/10.1016/j.envpol.2020. 115042

Şahin, Ü. A. (2020). The effects of COVID-19 measures on air pollutant concentrations at urban and traffic sites in Istanbul. Aerosol and Air Quality Research, 20, 1874-1885. https://doi.org/10.4209/aaqr.2020.05.023

Shehzad, K., Sarfraz, M., \& Shah, S. G. M. (2020). The impact of COVID-19 as a necessary evil on air pollution in India during the lockdown. Environmental Pollution, 266(1), 115080. https://doi.org/10.1016/j.envpol.2020.115080

Sicard, P. Marco, A., Agathokleous, E., Feng, Z., Xu, X., Paoletti, E., Rodriguez, J. J. D. \& Calatayud, V. (2020). Amplified ozone pollution in cities during the COVID-19 lockdown. Science of The Total Environment, (735), 139542.

Siciliano, B., Dantas, G., Silva, C. M. \& Arbilla, G. (2020). Increased ozone levels during the COVID-19 lockdown: Analysis for the city of Rio de Janeiro, Brazil. Science of The Total Environment, (737), 139765.

Tobías, A., Carnerero, C., Reche, C., Massagué, J., Via, M., Minguillón, M. C., Alastuey, A. \& Querol, X. (2020). Changes in air quality during the lockdown in Barcelona (Spain) one month into the SARS-CoV-2 epidemic. Science of The Total Environment, 138540.

TUIK. (2021a). Turkish Statistical Institute, Population and Housing Census 2020. Available at https://data.tuik.gov.tr/Bulten/ DownloadIstatistikselTablo? $\mathrm{p}=\mathrm{D} /$ iyuDY0YaNRJp8DX 69ESortYs YRQss36XKkV 5ynlsLTp4W Yhvc8 Woz6q Eb2bTRj (Received by 15 February, 2021a).

TUIK. (2021b). Turkish Statistical Institute, The number of road motor vehicles by province, 2020. Available at https://tuikweb.tuik.gov.tr/HbGetir.do?id=33658\&tb_id=2 (Received by 2 March, 2021b).

Unal, Y. S., Toros, H., Deniz, A., \& Incecik, S. (2011). Influence of meteorological factors and emission sources on spatial and temporal variations of $\mathrm{PM}_{10}$ concentrations in Istanbul metropolitan area. Atmospheric Environment, 45(31), 5504-5513.

Venter, Z. S., Aunan, K., Chowdhury, S. \& Lelieveld, J. (2020). COVID-19 lockdowns cause global air pollution declines. Proceedings of the National Academy of Sciences Aug 2020, 117 (32) 18984-18990. https://doi.org/10.1073/ pnas. 2006853117
Wang, B., Liu, J., Li, Y., Fu, S., Xu, X., Li, L., Zhou, J., Liu, X., He, X., Yan, J., et al. (2020). Airborne particulate matter, population mobility and COVID-19: A multi-city study in China. BMC Public Health, 20(2020), 1585.

Wetchayont, P. (2021). Investigation on the impacts of COVID19 lockdown and influencing factors on air quality in Greater Bangkok, Thailand. Advances in Meteorology, 2021(6697707) 11.

Wickham, H. (2016). ggplot2: Elegant graphics for data analysis. Springer, New York. Retrieved from http://ggplot2. org. Accessed 20 Oct 2020

Wickham, H., Francios, R., Henry, L., Müller, K. (2018). Dplyr: A grammar of data manipulation. Retrieved from https://cran.r-project.org/package=dplyr. Accessed 20 Oct 2020

Wikipedia. (2020). Timeline of the COVID-19 pandemic in Turkey. https://en.wikipedia.org/wiki/Timeline_of_the_COVID19_pandemic_in_Turkey, received date, November, 2020.

Wikipedia. (2021). Location of Marmara Region. https://en. wikipedia.org/wiki/Marmara_Region\#/media/File:LatransTurkey_location_Marmara_Region.svg, received date February, 10, 2021.

World Health Organization, (WHO). (2018). WHO air quality guidelines for particulate matter, ozone, nitrogen dioxide and sulfur dioxide: Global update 2018. Retrieved from https://www.who.int/news-room/fact-sheets/detail/ambient(outdoor)-air-quality-and-health

World Health Organization, (WHO). (2020). Coronavirus disease 2019 (COVID-19) situation report -209 available from: https://www.who.int/docs/default-source/coronaviru se/situation-reports/20200816-covid-19-sitrep-209.pdf? sfvrsn=5dde1ca2_2, Accessed 24th May 2021

Xu, K., Cui, K., Young, L. H., Hsieh, Y. K., Wang, Y. F., Zhang, J., \& Wan, S. (2020). Impact of the COVID-19 event on air quality in Central China. Aerosol and Air Quality Research, 20, 915-929. https://doi.org/10.4209/aaqr.2020. 04.0150

Yilmazkuday, H. (2021). Stay-at-home works to fight against COVID-19: International evidence from Google mobility data. Journal of Human Behavior in the Social Environment. https://doi.org/10.1080/10911359.2020.1845903

Zangari, S., Hill, D. T., Charette, A. T., \& Mirowsky, J. E. (2020). Air quality changes in New York City during the COVID19 pandemic. Science of the Total Environment, 742(2020), 140496. https://doi.org/10.1016/j.scitotenv.2020.140496

Zhu, Y., Xie, J., Huang, F., \& Cao, L. (2020). The mediating effect of air quality on the association between human mobility and COVID-19 infection in China. Environtal Research, 189, 109911. https://doi.org/10.1016/j.envres. 2020.109911

Publisher's Note Springer Nature remains neutral with regard to jurisdictional claims in published maps and institutional affiliations. 